\title{
La afectación de recursos del Patrimonio Municipal del Suelo a su conservación y ampliación *
}

\author{
«En España las normas no se cumplen suficientemente, hasta \\ tal punto que las colecciones del Boletín Oficial del Estado no \\ tienen más valor que el de un montón de papel viejo» «... el \\ grado de incumplimiento supera, con mucho, los índices de \\ tolerancia de cualquier país civilizado y aquí se vive en un es- \\ tado de anomia, de "fuera de la ley", que dificulta la conviven- \\ cia social y la realización de las tareas públicas.» \\ Alejandro NIETO, La «nueva» organización del desgobierno, \\ Editorial Ariel, S. A., Barcelona, 1997 (pp. 180-181).
}

Vicente-José Arnau Bernia

Interventor General del Ayuntamiento de Madrid

Sumario: INTRODUCCIÓN. 1. EL PATRIMONIO MUNICIPAL DEL SUELO EN LA LEGISLACIÓN Y DOCTRINA. 1.1. Antecedentes. 1.2. Ley de Régimen del Suelo y Ordenación Urbana de 12 de mayo de 1956. 1.2.1. Exposición de Motivos. 1.2.2. Texto legal: características fundamentales del PMS. 1.2.3. Los presupuestos especiales de Urbanismo. 1.2.4. Análisis doctrinal. 1.3. La Ley 19/1975, de 2 de mayo, de Reforma de la Ley sobre Régimen del Suelo y Ordenación Urbana y su Texto Refundido. 1.3.1. Exposición de Motivos y normativa fundamental. 1.3.2. Supresión de los Presupuestos especiales de Urbanismo. a) Los presupuestos «ordinarios» y los «de inversiones». b) El presupuesto «único». 1.3.3. La doctrina. 1.4. La Ley 8/1990, de 25 de julio, de Reforma del Régimen urbanístico y Valoraciones del Suelo y su Texto Refundido. 1.4.1. Los textos legales. 1.4.2. La doctrina. 1.4.3. Resoluciones jurisdiccionales sobre «afectación legal de recursos del PMS». a) Sentencia del Tribunal Supremo de 2 de noviembre de 1995. b) Sentencias de Tribunales Superiores de Justicia. 1.4.4. La STC 61/1997, de 20 de marzo. 1.4.5. La doctrina más reciente. 2. LA AFECTACIÓN LEGAL DE RECURSOS DE LOS PMS COMO NORMA DE ACCIÓN. 2.1. Normas de relación y normas de acción. 2.2. La impugnación de los Presupuestos de las Entidades locales. 2.3. Impugnación de los actos de gestión del PMS. 3. LA AFECTACIÓN LEGAL DE RECURSOS DEL PMS EN EL PRESUPUESTO DE LA GERENCIA MUNICIPAL DE URBANISMO DE MADRID. 3.1. Antecedentes. 3.2. Presupuesto de la GMUM de 2001. 4. RECAPITULACIÓN. ADDENDA. ABREVIATURAS UTILIZADAS. BIBLIOGRAFÍA.

* Salvo indicación en otro sentido, la cursiva, tanto del texto como de las notas a pie de página, es nuestra. 


\section{INTRODUCCIÓN}

El presente trabajo tiene por objeto estudiar los aspectos presupuestarios y contables que se derivan de la afectación de recursos urbanísticos (originariamente los ingresos obtenidos mediante enajenaciones y, posteriormente, también la sustitución del aprovechamiento correspondiente a la administración por su equivalente metálico) a la conservación y ampliación del Patrimonio Municipal del Suelo (PMS), establecida por la legislación de Régimen del Suelo y Ordenación Urbana.

Esta afectación legal de recursos urbanísticos a gastos concretos y determinados, concretamente para la conservación y ampliación del PMS, constituye una derogación del principio presupuestario de universalidad que, junto con otras, no menos importantes y significativas, tienen una relevancia en la Hacienda local, tanto española como de los restantes ordenamientos de tipo occidental, en sus perspectivas histórica y actual, de tal grado que no dudamos en considerar que constituye una de las características jurídico-financieras más relevantes de las Administraciones locales, que las separan rotundamente - en este aspecto- de las Haciendas centrales ${ }^{1} \mathrm{y}$ de las de tipo regional.

El amplio campo de aplicación de las afectaciones legales de recursos a ciertos tipos de gastos en las Haciendas locales ${ }^{2}$ es lo que ha propiciado, tanto históricamente como en los momentos actuales, soluciones presupuestarias y contables que facilitaran al máximo el seguimiento y el

\footnotetext{
${ }^{1}$ Entre la bibliografía que trata del principio de «no afectación» en la Hacienda Pública, puede consultarse: Comentarios a las Leyes Tributarias y Financieras, dirigidos por Narciso Amorós Rica (Tomo XLI, Vol. 1. ${ }^{\circ}$, Ley General Presupuestaria. Artículos 1 a 74), vid. Comentario artículo 23, pp. 207-212. Carlos Palao TaBOADA, Derecho Financiero y Tributario, vol. I (Introducción. Derecho presupuestario. Ingresos públicos no tributarios), 2. ${ }^{a}$ edición. Editorial Colex, Madrid, 1987, pp. 84-86. Miguel Ángel Martínez Lago, Manual de Derecho Presupuestario, Editorial Colex, Madrid, 1992, pp. 116-118.

${ }^{2}$ Esta materia sólo es tratada con cierta amplitud en los estudios y obras dedicados específicamente a los Presupuestos de las Entidades Locales, como: Vicente J. Arnau BerniA, «Anotaciones sobre los principios de unidad y nivelación en los Presupuestos de las Entidades Locales», RHAL, vol. XVIII, n. ${ }^{\circ}$ 53, mayo-agosto, 1988. Ed. de Derecho Reunidas. Ed. de Derecho Financiero. Madrid, pp. 246, 258-263, 265-267, 269-276, 277-278, 280-283, 286-290; «El régimen presupuestario local vigente: el presupuesto "único"». PALAU 14. Revista Valenciana de Hacienda Pública, enero-abril, 1989, pp. 150-152, 159, 164-165, 171-172; «El régimen presupuestario de las Entidades Locales», RHAL, vol. XX, n. ${ }^{\circ}$ 58, enero-abril, 1990, pp. 13-14, 16-17, 22, 25-29, 36-39, 41-42, 50-54, 64-65, 68-71, 80-83 y Manual de Presupuestos de las Entidades Locales, Monografías Jurídicas, Marcial Pons, Ediciones Jurídicas, S. A., Madrid, 1991, pp. 17-18, 23-26, 31-32, 34, 37-42, 46-48, 50-51, 61, 63-70, 80-82, 85, 96-97, 103-104, 201-205 y 231-239, y también Gloria Alarcón García, El Presupuesto general de los municipios, Editorial Tecnos, S. A., Madrid, 1996, pp. 51-56.
} 
control — tanto interno como externo - de las mismas para salir al paso de cualquier extralimitación o incumplimiento.

Como hemos venido exponiendo en todas nuestras publicaciones, cursos y seminarios impartidos sobre este tema, e insistiremos posteriormente, la legislación presupuestaria local española vigente y la regulación contable correspondiente, han abandonado completamente las soluciones tradicionales, y tampoco se han inspirado en los sistemas comparados que continúan dando solución a esta peculiaridad de las Haciendas locales ${ }^{3}$.

El tema objeto de nuestra atención sólo ha sido tratado de forma incidental o tangencial por parte de la doctrina administrativista que estudia el régimen de los PMS, al margen o con evidente desconocimiento de los condicionamientos presupuestarios y contables correspondientes.

En la doctrina jurídico-financiera no conocemos publicaciones que traten esta cuestión, sin desconocer alguna participación en cursos o seminarios por parte de Interventores y otros funcionarios de Administración Local ${ }^{4}$.

Hemos preferido transcribir literalmente las afirmaciones esenciales de los autores citados, a pesar de reconocer la mayor extensión que dicha metodología impondría a este trabajo, para presentarlas directamente al lector, tratando de eludir cualquier interpretación, por nuestra parte, que podría tacharse de subjetiva.

\footnotetext{
3 Además de estas «afectaciones» de recursos urbanísticos existen las muy importantes de la enajenación o gravamen de bienes patrimoniales, las contribuciones especiales, las subvenciones finalistas y las operaciones de crédito, canalizadas a través de una especial tipología presupuestaria, con su contabilidad separada, que garantizaba el seguimiento de la inversión de tales recursos a las finalidades legalmente establecidas, tema que hemos tratado insistentemente en nuestros trabajos citados anteriormente y además: «La gestión presupuestaria de las Entidades Locales», Presupuesto y Gasto Público, n. ${ }^{\circ}$ 8/1992, Ministerio de Hacienda, Madrid, pp. 20-22; «Acotaciones a la reforma presupuestaria y contable de las Entidades Locales», El Consultor de los Ayuntamientos, n. ${ }^{\circ} 23$ extra, 1992, pp. 2595-2597 y El saneamiento de las Haciendas Locales, Federación de Municipios de la Región de Murcia, 1999, pp. 17-19.

4 Vid. Agustín Murillo Cerrato, «Régimen económico, financiero y presupuestario de las Gerencias de Urbanismo» en la publicación Encuentro de Gerencias Municipales de Urbanismo, Gerencia Municipal de Urbanismo, Ayuntamiento de Madrid, 1994; Miguel Aguinaga Martínez, «Fiscalización en materia de urbanismo» en la obra colectiva El control interno en las Corporaciones Locales (abril-mayo 1997), Colegio Oficial de Secretarios, Interventores y Tesoreros de Administración Local de Castellón, Servicio de Publicaciones de la Diputación de Castellón, 1997, pp. 233-258 (especialmente pp. 235-244).
} 


\section{EL PATRIMONIO MUNICIPAL DEL SUELO EN LA LEGISLACIÓN Y DOCTRINA}

\subsection{Antecedentes}

Durante la vigencia de la denominada Legislación de Ensanche ${ }^{5}$, la Ley de Régimen Local, Texto articulado aprobado por Decreto de 16 de diciembre de 1950 (LRL 1950), al regular las «Obras y servicios municipales» (arts. 128-155), que se reprodujo en la Ley de Régimen Local, Texto articulado y refundido, aprobado por Decreto de 24 de junio de 1955 (LRL 1955), ordenaba que, en el plazo de tres años a partir de la entrada en vigor de la Ley, habría de formarse en todos los municipios «un Plan general de urbanización que comprenda la reforma, ensanche, higienización y embellecimiento de su aglomeración urbana, incluidas las superficies libres».

La gestión económica del «Ensanche» se realizaba a través de los denominados Presupuestos especiales de Ensanche, fórmula que establecía la separación de dicha actividad de las restantes municipales, y que facilitaba el seguimiento y rendición de cuenta diferenciada de tales fondos ${ }^{6}$.

El Reglamento de Bienes de las Entidades Locales, aprobado por Decreto de 27 de mayo de 1955 (RB 1955), al tratar del «Patrimonio de las Entidades locales», dedicaba una sección a la «Ordenación urbana» y «Patrimonio municipal» (arts. 13-15), donde se determinaba que «los respectivos Ayuntamientos habrán de constituir Patrimonios municipales de suelo», obligación que se imponía «con el fin de prevenir, encauzar y desarrollar la expansión urbana de las poblaciones mayores de 50.000 habitantes o capitales de Provincia y para facilitar los planes de ordenación urbana» (art. 13).

\footnotetext{
${ }^{5}$ Ley de 29 de junio de 1864 y su Reglamento de 25 de abril de 1867, Leyes de Ensanche de Poblaciones de 22 de diciembre de 1876 y 26 de julio de 1892, y Ley de 18 de marzo 1895 sobre Saneamiento y Reforma Interior de Grandes Poblaciones. Sobre esta legislación histórica puede consultarse la obra de Martín Bassols Coma, Génesis y evolución del Derecho urbanístico español, 1812-1956, Editorial Montecorvo, Madrid, 1973.

${ }^{6}$ Sobre estos Presupuestos especiales de Ensanche puede consultarse Federico A. FerRán Salvador, Contabilidad Municipal, Establecimiento Litográfico de José Martínez, Barcelona, 1900, tomo I, pp. 842-864; tomo II, pp. 495-513; Antonio SAURA PACHeCo, Nuevo sistema de contabilidad municipal, Colegio Nacional de Secretarios, Interventores y Depositarios de Administración Local, Madrid, 1947, pp. 279-280 y Vicente J. Arnau Bernia, Manual de Presupuestos de las Entidades Locales, Monografías Jurídicas, Marcial Pons Ediciones Jurídicas, S. A., Madrid, 1991, pp. 31-32, 48, 63 y 67.
} 
El artículo 15 del RB 1955 disponía que «Los bienes de propios que resultaren incluidos en los planes generales de ordenación urbana quedarán afectos al Patrimonio municipal del suelo».

La regulación de estos incipientes Patrimonios Municipales del Suelo se cerraba con el mandato de que tanto la adquisición como la enajenación de sus terrenos habían de estar «sujetas a los planes generales de ordenación y a los programas de actuación consiguientes» (art. 14 RB 1955).

Como ha explicitado la doctrina, antes del RB 1955 no ha existido normativa urbanística que obligara a la constitución de un PMS. Así, ni bajo el período de la denominada legislación de Ensanche, ni en el Estatuto Municipal de 1924, ni tampoco durante la aplicación de la legislación de los años cuarenta (Leyes de Ordenación Urbana de Madrid, 1946; de Bilbao, 1946; y de Valencia, 1949). Sin embargo, tanto por aplicación de las Leyes de Ensanche, como por la legislación — citada - de creación de órganos urbanísticos, se produjo una «patrimonialización» y «especialización» contable de dicha actividad urbanistica a través del instrumento presupuestario (Presupuestos especiales de Ensanche), quedando afectada a la realización de los planes de Ensanche, como subrayó en su día el profesor E. PÉREZ BOTIJA, que afirmó cómo, respecto de las Leyes de Ordenación Urbana de 1946 y 1949, «se adscribe una masa de bienes a estos fines. Se patrimonializan los servicios urbanísticos en una especie de "peculio administrativo"» ${ }^{7}$.

Como también se ha puntualizado doctrinalmente, la LRL 1950 y LRL 1955 no previeron la creación del PMS y que «fue el Reglamento de Bienes de las Entidades Locales [RB 1955] el que de forma rotunda, aunque elemental, mandó ("habrán de constituir") a los Ayuntamientos de poblaciones mayores de 50.000 habitantes o de capitales de provincia, constituir P. m. s... y, así, esta regulación reglamentaria constituye el embrión que habría de desarrollar la Ley del Suelo» ${ }^{8}$.

Esta técnica de sistemática adquisición pública de suelo, introducida por el RB 1955, ha sido como el «exiguo e inmediato antecedente» de la constitución obligatoria, establecida posteriormente por la LS $1956{ }^{9}$.

\footnotetext{
7 «Introducción al Derecho Urbanístico Español», primera parte del Derecho Urbanístico Español (Conceptos y Legislación), Instituto de Estudios de Administración Local, Madrid, 1950, p. 57.

8 Alfonso Pérez Moreno, «Aspectos jurídicos del Patrimonio Municipal del Suelo», Revista de Derecho Urbanístico, n. ${ }^{\circ}$ 10, Editorial Montecorvo, Madrid, 1968, pp. 37-40.

9 Eduardo García de Enterría, Luciano Parejo Alfonso, Lecciones de Derecho Urbanístico, Editorial Civitas, S. A., Madrid, 1981, pp. 588-589.
} 


\subsection{Ley de Régimen del Suelo y Ordenación Urbana de 12 de mayo de 1956}

\subsubsection{Exposición de Motivos}

La Ley de Régimen del Suelo y Ordenación Urbana de 12 de mayo de 1956 (LS 1956), como literalmente indica su Exposición de Motivos, pretende, en términos generales, «superar los defectos de la actual situación» centrada en la contemplación de la acción urbanística desde la perspectiva puramente local, la configuración del «régimen del suelo» confiada a la más amplia autonomía de voluntad y libertad de tráfico, la previsión de la «ejecución de las urbanizaciones» sin imponer la observancia de un orden de prioridades, la «financiación» a cargo de los fondos generales municipales con la permisión de un posterior reintegro parcial a costa de los beneficiados de la obra, estando todo ello unido a la sugestión ejercida por los «proyectos a corto plazo».

La LS 1956 se basaba, fundamentalmente, en la regulación del «planeamiento», y al tratar del «régimen jurídico del suelo», la misma Exposición de Motivos de la Ley, refiriéndose a «la adquisición de la totalidad de las superficies afectadas por el planeamiento» como fuera del alcance de «los medios económicos del Estado, de los Municipios y de las Provincias», añadía que sin embargo era «asequible a las Corporaciones locales adquirir paulatinamente terrenos que puedan servir como reguladores de precio en el mercado de solares».

Esta argumentación, según la misma Exposición de Motivos, determinaba que «Considerándolo así, la Ley prevé la constitución de "patrimonios municipales del suelo", con carácter obligatorio para los Municipios de población superior a 50.000 habitantes».

La LS 1956, al tratar de los «recursos económicos», se refería —en la tan repetida Exposición de Motivos - a la obligación impuesta a los Ayuntamientos capitales de provincia o de más de 50.000 habitantes de:

- Formar un presupuesto especial de urbanismo.

- Consignar en sus presupuestos cantidades equivalentes al 5 por 100 de su importe para la formación e incremento del «patrimonio municipal del suelo».

- Consignar otro 5 por 100 para la ejecución de urbanizaciones. 


\subsubsection{Texto legal: características fundamentales del PMS}

La LS 1956, dentro de su Título II, «Régimen urbanístico del suelo», dedicó su Capítulo II al «Patrimonio municipal del suelo» (arts. 72-76).

Los Ayuntamientos obligados a constituir su respectivo Patrimonio Municipal del Suelo (PMS) eran, según su artículo 72:

- Capitales de provincia.

- De población superior a 50.000 habitantes.

- Los que voluntariamente lo acordaran.

- Los que señalare la Comisión Central de Urbanismo.

Limitándonos estrictamente al ámbito de este trabajo, debemos destacar las siguientes características del PMS:

- Finalidad: "prevenir, encauzar y desarrollar técnica y económicamente la expansión de las poblaciones, y se adscribirá a la gestión urbanística para la inmediata preparación y enajenación de solares edificables y reserva de terrenos de futura utilización» (art. 72-2 LS 1956).

- Afectación de terrenos: «cuando resultaren incluidos en el Plan bienes de propios quedarán afectados al Patrimonio municipal del suelo» (art. 73-3 LS 1956).

- Afectación de recursos: «Los ingresos obtenidos por la gestión urbanística mediante enajenación de terrenos del Patrimonio, se destinarán a la conservación y ampliación del mismo» (art. 76 LS 1956)

Con estas tres características queremos insistir especialmente en los aspectos básicos de los PMS: el motivo, finalidad u objetivo que el legislador tuvo para la constitución, el carácter - implícito- de patrimonio separado de los restantes bienes municipales, y, sobre todo, la «afectación legal» de recursos (ingresos) obtenidos por su enajenación exclusivamente para su conservación y ampliación, elementos que permanecerán - como se verá - en las modificaciones legales sucesivas que sólo añadirán algunos aspectos sobre los que se incidirá en su momento. 


\subsubsection{Los Presupuestos especiales de Urbanismo}

Los Ayuntamientos de capitales de provincia o de más de 50.000 habitantes tenían la obligación, y los restantes podían - según el artículo 176-1 LS 1956 - formar un Presupuesto especial de Urbanismo «para atender a las obligaciones derivadas de esta Ley, que se regirá por lo dispuesto para los ordinarios en la Ley de Régimen Local» ${ }^{10}$.

En el estado de ingresos de dichos Presupuestos únicamente podían figurar (art. 176-2 LS 1956) los siguientes recursos:

a) Subvenciones, auxilios y donativos concedidos para fines urbanísticos.

b) Asignaciones de igual índole en el Presupuesto ordinario de la propia Corporación.

c) Productos de las enajenaciones de terrenos afectos al Patrimonio municipal del suelo.

d) Exacciones autorizadas o que en lo sucesivo se autorizaren.

e) Arbitrios no fiscales y multas, y

f) Rendimientos de empréstitos, préstamos u otras formas de anticipo.

En el estado de gastos, «además de las consignaciones correspondientes al importe de los estudios, proyectos y obras de primera urbanización dispuestas por Planes y Proyectos aprobados conforme a la presente Ley, sólo podrán incluirse... las cantidades necesarias para atender al servicio de intereses y amortización de los empréstitos, préstamos u otras formas de anticipo..., así como una partida de "Imprevistos" para dotar aquellos gastos necesarios y urgentes que pudieran surgir en el desarrollo del Presupuesto» (art. 176-3 LS 1956).

Una vez ejecutadas las obras, «los gastos de entretenimiento, conservación y modificación de la urbanización serán de cargo del Presupuesto ordinario» (art. 176-4 LS 1956).

Las subvenciones y asignaciones a favor del Presupuesto especial de Urbanismo, así como la emisión de obligaciones y concertación de préstamos, se regulaban en los artículos 177 a 180 LS 1956.

10 Vid. Antonio Saura Pacheco, Teoría y práctica de los Presupuestos municipales, Ediciones Municipalía, Madrid, 1958, pp. 91, 100, 318, 355-356. Vicente J. Arnau Bernia, Manual de Presupuestos de las Entidades Locales, cit., pp. 63-64, 67-70 y 80. 
Concretamente, el artículo 178 LS 1956 establecía las siguientes «asignaciones» con cargo al Presupuesto ordinario, y que debían figurar por el mismo importe en el estado de ingresos de los Presupuestos especiales de Urbanismo:

- Un 5 por 100 de su importe durante el número de anualidades que exigiera el desarrollo del Plan, y

- Otro 5 por 100, al menos, del mismo Presupuesto ordinario para la ejecución de urbanizaciones previstas.

Entre las exacciones, además de los derechos y tasas y las contribuciones especiales, se regulaban los arbitrios municipales sobre ordenación urbanística, y sobre aumento del volumen de edificación, participaciones en las cuotas del Tesoro de la contribución territorial sobre la riqueza urbana, y recargos extraordinarios sobre la misma y sobre el arbitrio de incremento del valor de los terrenos (arts. 181-188 LS 1956) ${ }^{11}$.

La doctrina administrativa no ha dedicado una atención suficiente hacia los aspectos presupuestarios y contables de la regulación de los PMS; sin embargo, en algún caso, se ha subrayado - ya en los primeros momentos de la constitución de tales patrimonios-, al analizar los obstáculos hasta entonces presentes, la conveniencia de «perfeccionar los criterios legales y los mecanismos presupuestarios y contables para evitar la actual desviación de los créditos que deben destinarse a la formación de los patrimonios de suelo», para lo cual se debería ${ }^{12}$ :

- «La Ley del Suelo, y los Presupuestos estatales y locales podrían fijar la cantidad que se deba dedicar a adquirir terrenos con total independencia de la destinada a urbanizaciones u otras atenciones urbanísticas.»

- «La fiscalización presupuestaria y contable de las Corporaciones locales podría esforzarse más en evitar que se infrinja la obligación legal de invertir en suelo».

\footnotetext{
${ }^{11}$ Un amplio estudio sobre todos los recursos de los Presupuestos especiales de Urbanismo puede consultarse en Adolfo CARRETero Pérez, «Las Haciendas locales y la gestión económica del urbanismo», Revista de Economía y Hacienda Local, vol. IV, n. ${ }^{\circ} 12$, septiembre-diciembre 1974, Editorial de Derecho Financiero, Madrid, pp. 428-462.

12 Jose María Boquera Oliver, «El patrimonio municipal de suelo», en la obra colectiva Problemas del urbanismo moderno, Instituto de Estudios de Administración Local, Madrid, 1967, p. 211, habiéndose omitido aquí toda alusión a las «subvenciones», por tratarse de regulación sólo aplicable en el momento de concretarse dicho trabajo.
} 
Estas expresiones demuestran una preocupación hacia los aspectos presupuestarios y contables de los PMS, que no sólo entonces, sino tampoco con posterioridad, incluso en nuestros días, nunca han sido reglamentados por las autoridades de la Administración central encargadas de los mismos (Ministerio de Hacienda), ni por las que tenían la regulación o tutela de sus contornos jurídico-administrativos (Ministerios de la Vivienda y de Obras Públicas y Urbanismo) que, durante todo el transcurso histórico, no han tenido la menor coordinación entre sí para precisar, delimitar, fomentar, vigilar ni controlar la actividad municipal en este ámbito de los patrimonios de suelo.

Se deduce de lo transcrito que todos los ingresos y los gastos de estos Presupuestos especiales de Urbanismo eran propios, específicos, de la acción urbanística, y de ahí la solución legal de su singularidad presupuestaria para facilitar la contabilidad, control y seguimiento de dicha función pública urbanizadora, con total independencia del resto de las actividades $\mathrm{y}$ atenciones municipales.

El Presupuesto especial de Urbanismo, con tramitación paralela al Presupuesto ordinario y duración también anual, debía regirse por todas las normas aplicables a este último que fueran compatibles con la especialidad de su régimen específico y, como ha quedado explicitado, tenían un contenido prácticamente equivalente al de los Presupuestos extraordinarios, dedicados a gastos de primer establecimiento, de inversión, o de capital, con la única excepción - ya reseñada - de permitir la consignación en su estado de gastos de la anualidad de amortización de préstamos y empréstitos, que por ser un gasto ordinario era propio, en aquella época, de los Presupuestos ordinarios.

Este carácter mixto de su estructura intrínseca estaba determinado por el interés del legislador de canalizar «todos» los gastos de urbanismo a través de tales Presupuestos especiales.

La separación de tales Presupuestos especiales de Urbanismo, de los ordinarios, de los extraordinarios y de los otros posibles especiales, que comportaba la de su contabilidad y rendición de cuentas, permitían un control directo, claro y transparente de todos los gastos e ingresos de la gestión urbanística local, y muy concretamente, por lo que nos interesa de modo particular, de la afectación de los recursos (ingresos) obtenidos mediante la enajenación de bienes del PMS a su conservación y ampliación.

Según los datos facilitados por la Sección especial de Estadística del Ministerio de la Gobernación, los Presupuestos especiales de Urbanismo 
de los años 1966 a 1970 fueron, para cada ejercicio, en número de 97, 96, 99, 104 y 105 , suponiendo los siguientes totales acumulativos en millones de pesetas: $2.366,3 ; 3.096,3 ; 3.236,4 ; 4.829,1$ y 4.948 , y la estructura de sus ingresos referida al último de los ejercicios indicados era la siguiente, en porcentajes: aportaciones de otros presupuestos (46,2 por 100), enajenación de bienes (20,9 por 100$)$, contribuciones especiales $(23,2$ por 100$)$, tasas $(1,8$ por 100$)$, lo que en términos resuntivos refleja la financiación dominante por asignaciones de otros presupuestos y por contribuciones especiales, siguiendo de cerca a estas últimas exacciones, las enajenaciones patrimoniales, y quedando en un lugar prácticamente insignificante los arbitrios y demás ingresos tributarios de carácter urbanístico ${ }^{13}$.

\subsubsection{Análisis doctrinal}

La doctrina jurídico-administrativa coincide en términos generales en evaluar como fracaso, o fracaso relativo, la implantación de los PMS por la LS 1956.

Ciertamente, la LS 1956 fue la primera norma legal que impuso en España la creación de los PMS; sin embargo, no transcurrido mucho tiempo desde su entrada en vigor, se pudo afirmar que, «transcurridos más de diez años de su vigencia, es mínima la cifra de municipios que han cumplido en ese particular las normas de la Ley», alegándose por autores como José María BoQUERA Oliver ${ }^{14}$ obstáculos psicológicos, sociológicos, económicos y técnicos (regulación insuficiente), así como la «pasividad de los Ayuntamientos de nuestras grandes ciudades...» ${ }^{15}$, la perturbación de la creación del Ministerio de la Vivienda, integrando en el mismo los órganos responsables del urbanismo y propiciando una separación entre los sectores de Urbanismo y Régimen local que ofrecía cada día mayores inconvenientes ${ }^{16}$, por lo que «a la vista de tan deficitario balance de resultados prácticos» se formulaba la pregunta de «si debe o no mantenerse la técnica del Patrimonio municipal del suelo» ${ }^{17}$.

\footnotetext{
13 José L. LAmpreave, «La financiación del urbanismo (un acercamiento a su fundamentación doctrinal y a la evaluación de sus resultados en España)», Hacienda Pública Española, n. ${ }^{\circ}$ 22, Instituto de Estudios Fiscales, año 1973, pp. 147-172 (especialmente pp. 164-168).

14 «El Patrimonio municipal del suelo», cit., pp. 206-212.

15 Enrique Serrano Guirado, «Planificación territorial, Política del suelo y Administración local», en Problemas Políticos de la Vida Local, tomo III, Madrid, 1963, pp. 276.

16 Eduardo García de EnTERría (Apuntes de cátedra, curso 1965-1966), p. 76.

17 Alfonso Pérez Moreno, «Aspectos jurídicos del Patrimonio municipal del suelo», cit., pp. 33-37.
} 
Prueba de la resistencia y pasividad de los Ayuntamientos en la constitución de los PMS fue la resolución del Tribunal Económico-Administrativo de Sevilla, de 14 de noviembre de 1960, consecuencia de la impugnación del Presupuesto ordinario del Ayuntamiento de dicha capital, realizada por el Colegio Oficial de Arquitectos, de Andalucía Occidental, Badajoz y Canarias, por falta de consignación de las asignaciones legalmente establecidas para constitución de dicho patrimonio, lo que permitió afirmar en su día que el Ayuntamiento de Sevilla era «en la actualidad uno de los pocos Municipios españoles que tienen constituido el P.m.s.» ${ }^{18}$.

Alfonso PÉrez Moreno, al analizar el carácter del PMS, subraya cómo en relación con la «teoría del patrimonio separado», en la doctrina privatista su punto clave está «en la responsabilidad por deudas, es decir, en ser un centro de imputación de obligaciones», mientras que «en el Derecho administrativo debe prevalecer el principio de garantía, de afectación, de adscripción o vinculación a un fin determinado», siendo, por consiguiente, «efecto principal del patrimonio el principio de subrogación real, en cuanto que la cosa, el bien, queda sustituido por su precio o por el bien con que se hubiera permutado» ${ }^{19}$.

Al referirse el mismo autor al artículo 76 de la LS 1956 afirma textualmente cómo «acoge directamente el efecto subrogatorio al disponer que "los ingresos obtenidos por la gestión urbanística mediante enajenación de terrenos del Patrimonio se destinarán a la conservación y ampliación del mismo"» 20 .

En términos de la mayor amplitud, y refiriéndose a la LS 1956 en su conjunto, la doctrina ha indicado cómo dicha Ley fracasó por ser «un raro ejemplo en nuestro Derecho público de norma jurídica que se adelanta a su tiempo sin una base doctrinal previa, que en aquellas fechas no existía pura y simplemente», $\mathrm{y}$, quizá precisamente por su «coherencia técnica interna», ya que «la actividad planificadora se desarrolló con extraordinaria lentitud...», generando «un peligroso distanciamiento entre la norma... y la realidad...» y «... la pérdida de credibilidad de aquélla....» y también por «una correlativa escasez de suelo apto para la edificación (ya

\footnotetext{
18 Alfonso Pérez Moreno, «Aspectos jurídicos del Patrimonio municipal del suelo», cit., pp. 41-48.

19 Alfonso Pérez Moreno, «Aspectos jurídicos del Patrimonio municipal del suelo», cit., pp. 64-65.

${ }^{20}$ Alfonso Pérez Moreno, «Aspectos jurídicos del Patrimonio municipal del suelo», cit., p. 66.
} 
que sólo los planes podían crearlo), que contribuyó a exacerbar la tendencia especulativa y las tensiones inflacionistas», sin olvidar que «contribuyó también decisivamente el fallo de otra de las piezas clave de la Ley, los patrimonios públicos de suelo, cuya función teórica era la de influir en el mercado de solares como mecanismo indirecto de regulación de los precios...» ${ }^{21}$.

Los Profesores GARCÍA DE EnTERRÍA y PAREJo AlFonso indicaron que, a pesar de ser una técnica «absolutamente generalizada en el Derecho extranjero», había de tenerse presente que, «hasta la promulgación de la LS de 1956, el Derecho español carecía de tradición en materia de adquisición pública de suelo», y que la constitución obligatoria de los PMS en los supuestos previstos legalmente comportaba además «la reinversión en su conservación o ampliación de los productos de las enajenaciones de suelo» ${ }^{22}$.

Tal sistema «fue considerado como un progreso decisivo», siendo así que más bien «la ingenuidad de esta previsión es hoy bien notoria con sólo observar que los patrimonios municipales de suelo se han constituido normalmente todo lo más como una simple rúbrica formal bajo la que se agrupan los terrenos de que los municipios son titulares por unos u otros conceptos, sin que haya existido propiamente una política coherente y continuada de adquisición de suelo con la vista puesta en las finalidades legales de los patrimonios de suelo; más aún, se pueden contar con los dedos de una mano los municipios que han cumplimentado el mandato legal de afectación a dichas finalidades del 5 por 100 de su presupuesto ordinario» ${ }^{23}$.

También se ha dicho que «el sistema ha fracasado, sencillamente porque no ha logrado aportar una cantidad mínimamente significativa de suelo al proceso urbanizador español», ya que la «filosofía económica» subyacente a dicho sistema «ha sido una completa ilusión, pues es bien claro que la oferta pública de suelo no ha tenido prácticamente ninguna incidencia reductora en el proceso de incremento del valor del suelo» ${ }^{24}$.

\footnotetext{
21 Tomás-Ramón Fernández Rodríguez, Manual de Derecho Urbanístico, Publicaciones Abella, Madrid, 1980, pp. 18-21.

22 Eduardo García de Enterría y Luciano Parejo Alfonso, Lecciones de Derecho Urbanístico, cit., pp. 576 y $588-589$.

23 E. García de Enterría y L. Parejo Alfonso, Lecciones de Derecho Urbanístico, cit., p. 589.

${ }^{24}$ E. García de Enterría y L. Parejo Alfonso, Lecciones de Derecho Urbanístico, cit., p. 590.
} 


\subsection{La Ley 19/1975, de 2 de mayo, de Reforma de la Ley sobre Régimen del Suelo y Ordenación Urbana y su Texto refundido}

\subsubsection{Exposición de Motivos y normativa fundamental}

La Exposición de Motivos de la Ley 19/1975, de 2 de mayo, de Reforma de la Ley sobre Régimen del Suelo y Ordenación Urbana (LS 1975) reconoció «la insuficiencia», que "no ofrece lugar a dudas» de los instrumentos de «los patrimonios públicos de suelo para ser utilizados como reguladores del mercado» y de «la normativa sobre enajenación forzosa de solares sin edificar» sobre la que «la Ley del Suelo [LS 1956] basó su política antiespeculativa fundamentalmente» [punto II, letra e), párrafo segundo].

La LS 1975 no afectó a la regulación de la LS 1956, en las siguientes materias, que permanecieron con su mismo texto, pasando prácticamente con redacción idéntica al Texto refundido de la Ley sobre Régimen del Suelo y Ordenación Urbana, aprobado por Decreto 1346/1976, de 9 de abril (TRfdo.LS1976):

- Patrimonio Municipal del Suelo (arts. 72-76 LS1956).

- Presupuestos especiales de Urbanismo (art. 176 LS1956).

- Subvenciones y asignaciones (arts. 177-180 LS1956).

Las referencias que en el texto de la LS 1956 aludían a la Comisión Central de Urbanismo quedaron sustituidas en la redacción del TRfdo.LS1976 por el Ministerio de la Vivienda.

Por consiguiente, se mantienen con su mismo literal los preceptos legales que hacen referencia al PMS en cuanto a su:

- Finalidad (art. 89-2 TRfdo.LS1976, idéntico al art. 72-2 LS1956).

- Afectación de terrenos (art. 90-3 TRfdo.LS1976, idéntico al art. 73-3 LS1956).

- Afectación de recursos (art. 93 TRfdo.LS1976, idéntico al art. 76 LS1956). 


\subsubsection{Supresión de los Presupuestos especiales de Urbanismo}

a) Los presupuestos «ordinarios» y los «de inversiones»

Los «Presupuestos especiales de Urbanismo» ${ }^{25}$ quedaron suprimidos, lo mismo que los restantes «especiales» y también los «extraordinarios», según se determinó en el Real Decreto-Ley 3/1981, de 16 de enero, tramitado posteriormente y aprobado como Ley 40/1981, de 28 de octubre, sobre Régimen Jurídico de las Corporaciones Locales, quedando integrados los saldos de los mismos no liquidados, así como los que se encontraran en situación de pendientes de aprobación en un «presupuesto de inversiones» de $1983^{26}$.

Esta nueva regulación presupuestaria local sólo admitía dos tipos de presupuestos: los «ordinarios», donde se recogían los recursos y gastos de tal naturaleza, y los «de inversiones», donde figuraban los recursos y gastos de inversión, o de capital. Su reglamentación previno que tal dualidad presupuestaria debería darse, en su caso, respecto a todas las personificaciones jurídico-públicas integradas en el ámbito de cada Entidad local.

Para la materia que nos ocupa en este trabajo, a las atenciones y recursos de urbanismo les sería de aplicación esta nueva tipología de presupuestos cuando su gestión estuviera encomendada a una personificación jurídico-pública (Gerencia de Urbanismo, Organismo autónomo).

La desaparición de los «Presupuestos especiales», singularmente por lo que se refiere a los de Urbanismo, unida a la de los «extraordinarios», consecuencia del RD-ley 3/1981, y la Ley 40/1981 antes citados, por ser todos ellos canalizadores de gastos de primer establecimiento, de inversión, o de capital, provocó la integración — como se ha dicho anteriormente- en «un» «presupuesto de inversiones», donde se agruparon, o mejor confundieron, todos los recursos y atenciones de los diversos presupuestos existentes o en trámite de formación, perdiendo su individualidad y la garantía que suponía su contabilización y rendición de cuentas propias y específicas, de no existir una personificación jurídico-pública - como acabamos de matizar-, único caso en que tal singularización y separación subsistiría.

\footnotetext{
25 Jesús González Pérez, Comentarios a la Ley del Suelo, tomo II, 4. a edición, Editorial Civitas, S. A., Madrid, 1981, pp. 1508-1512, glosó la regulación de tales Presupuestos especiales de Urbanismo en obra publicada el mismo año en que se dispuso su desaparición.

${ }^{26}$ Vid. Vicente J. Arnau Bernia, Manual de Presupuestos de las Entidades Locales, cit., pp. 79-86.
} 


\section{b) El presupuesto «único»}

Las Leyes 7/1985, de 2 de abril, reguladora de las Bases del Régimen Local (LBRL) y 39/1988, de 28 de diciembre, reguladora de las Haciendas Locales (LRHL), dejaron sin efecto la dicotomía apenas puesta en práctica - en una solución sustancialmente equivalente a la distinción en el Derecho presupuestario local alemán de Verwaltungshaushalt y Vermögenshaushalt (presupuesto de administración, presupuesto de patrimonio) ${ }^{27}$ — de presupuesto «ordinario»y «de inversión», y estableció el denominado presupuesto «único».

Como ya hemos indicado, desde su instauración en la Hacienda Local, y continuamos subrayando desde entonces —en todos los trabajos sobre temas presupuestarios ya mencionados-, tal presupuesto «único» no deja de ser una mera expresión, por cierto, poco significativa, ya que desde 1985-1988, e incluso anteriormente, la patente proliferación de personificaciones jurídicas, tanto públicas como privadas, en el ámbito de muchas Entidades locales, debería exigir el calificativo de presupuestos «múltiples», ya que cada personificación — que no tiene límites en su incremento- exige la existencia de un presupuesto «único» para todas y cada una de ellas.

Dentro de esta multiplicación presupuestaria - por entenderse en nuestro ordenamiento correlacionados los institutos de «presupuesto» y de «descentralización funcional»- $\mathrm{y}$ en términos idénticos a lo dicho para el período 1982-1986 (presupuestos «ordinarios» y «de inversiones»), tan sólo existiría una individualización y separación de las operaciones de urbanismo, en su doble vertiente de recursos y gastos, cuando se hubieran atribuido las mismas a una personificación jurídica dentro de la Entidad local, utilizando o no la fórmula quizá más adecuada de la «Gerencia de Urbanismo».

Caso de no existir tales personificaciones para los fines «urbanísticos», era patente la falta de tratamiento adecuado de las «afectaciones legales de recursos», tanto los de los PMS como de los restantes de tipo de inversión (enajenación o gravamen de bienes patrimoniales, contribuciones especiales, subvenciones finalistas para obras y servicios, crédito público), en los órdenes presupuestario y contable, para los que no se quiso

27 Sus rasgos esenciales pueden consultarse en Vicente J. ARNAU BERNIA, «Anotaciones sobre los principios de unidad y nivelación en los Presupuestos de las Entidades locales», Revista de Hacienda Autonómica y Local, vol. XVIII, n. 53 (mayo-agosto 1988), pp. 267-272. 
acudir siquiera a las soluciones dadas por los sistemas locales comparados más avanzados 28 .

\subsubsection{La doctrina}

La Reforma de 1975, como ha quedado reseñado anteriormente, mantuvo tal como estaba la regulación originaria de los PMS, por lo que por su «ineficacia operativa demostrada» constituía «objeto» de una primera crítica, que debía extenderse a la supresión del deber de constitución de dichos Patrimonios del Suelo por parte de las Diputaciones Provinciales. Constituyó elemento positivo de la nueva legislación el establecimiento de una fuente importante del incremento del PMS, como fue el 10 por 100 del aprovechamiento del sector en el suelo urbanizable programado y en el no programado; mientras que la nueva regulación del sistema de expropiación volvía a reducir a la misma a un sistema de actuación del planeamiento previo, lo que impedía toda política de adquisición no sólo al margen de esto, sino con anticipación a sus determinaciones ${ }^{29}$.

Los trabajos preparatorios de la reforma a que aludimos se iniciaron en 1972 para flexibilizar los planes, fijación de criterios materiales de planeamiento, profundización del régimen de cesiones obligatorias y gratuitas, así como de los mecanismos de reparto de beneficios y cargas de la ordenación, y se encontraron con el estallido de la crisis económica, por lo que el nuevo contexto, moviéndose todavía desde la «óptica del ensanche», estuviera fuera de lugar ${ }^{30}$.

La doctrina insistió en que «la reforma de 1975 no permite contemplar con optimismo la posibilidad de constitución de reservas de suelo importantes cuya gestión pudiera llegar a permitir un control efectivo de las tendencias espontáneas del mercado», ya que, entre otras causas, la vía expropiatoria [arts. 134 y 145 TRfdo.LS1976] «obliga a atenerse a un horizonte de ocho años», por lo que «es sólo útil realmente para actuar en el presente, pero no para constituir verdaderas reservas de futuro», a lo que coadyuva el precio de adquisición de suelo — el «valor urbanístico»-, encarecido notablemente por la LS 1975. De ahí que se subrayara que la

\footnotetext{
28 Vid. en este sentido Vicente J. Arnau Bernia, Manual de Presupuestos de las Entidades Locales, cit., pp. 96-98, 103-104, 203-205 y 231-239, donde se subrayan las ventajas de los presupuestos locales en Alemania y Francia.

29 E. García de Enterría y L. Parejo Alfonso, Lecciones de Derecho Urbanístico, cit., p. 591.

30 Tomás-Ramón Fernández Rodríguez, Manual de Derecho Urbanístico, Edición 1980, cit., pp. 22-25.
} 
dotación de los PMS «tampoco ha mejorado sustancialmente como para permitir un cambio significativo de la situación anterior», a pesar del refuerzo nada despreciable de la cesión obligatoria y gratuita del 10 por 100 del aprovechamiento medio y de la asignación del 5 por 100 del Presupuesto municipal ordinario [arts. 84-3 y 194-1 TRfdo.LS1976], siendo la función de tales patrimonios municipales «solamente una acción auxiliar, nunca decisiva, en la gestión municipal», por lo que con estas consideraciones es como hay que «interpretar el alcance real de la enfática declaración contenida en el artículo 89-2 TRfdo.LS1976, sobre su "finalidad" de "prevenir, encauzar y desarrollar técnica y económicamente la expansión de las poblaciones y se adscribirá a la gestión urbanística para la inmediata preparación y enajenación de solares edificables y reserva de terrenos de futura utilización"» ${ }^{31}$.

El Profesor GonZÁLEZ PÉREZ, al referirse a la naturaleza jurídica de los PMS, subraya cómo «están sujetos a un régimen peculiar y diferenciado. Constituyen un "patrimonio separado", en sentido técnico, dentro del patrimonio de la entidad local... Y desde el momento en que bienes de propios resultaren incluidos en el plan, "quedarán afectados al patrimonio municipal del suelo". Lo que supone la imposibilidad de designarlos a fin distinto del peculiar de este patrimonio, régimen peculiar de gestión y de enajenación, constituyendo el producto de sus enajenaciones uno de los recursos del presupuesto especial de urbanismo»; y abunda también en que su funcionalidad «como instrumento en la lucha contra la especulación ha sido hasta ahora inoperante, apuntando en este sentido "... que no existe un político que destine parte del presupuesto de hoy para una labor cuyos frutos serían recogidos por sus sucesores"» 32 .

El mismo autor, al tratar del «régimen económico del patrimonio del suelo», insiste en su calificación de "patrimonio separado», por lo que «la masa de bienes que integran el patrimonio del suelo está afectada a la finalidad que la Ley asigna y no a ninguna otra», añadiendo que «el patrimonio municipal del suelo ha de tener el debido reflejo presupuestario. Así, cuando exista presupuesto especial de urbanismo - o, en otro caso, en el ordinario- deberá señalarse el especial destino de los bienes de este patrimonio» ${ }^{33}$.

\footnotetext{
31 Tomás-Ramón Fernández Rodríguez, Manual de Derecho Urbanistico, Edición 1980, cit., pp. 117-119.

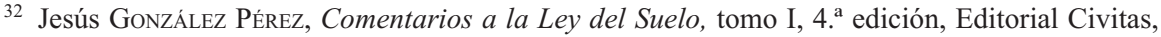
S. A., Madrid, 1981, pp. 698-700.

33 Jesús González Pérez, Comentarios a la Ley del Suelo, tomo I, cit., p. 709.
} 
Por lo que se refiere a los «ingresos de la enajenación de los terrenos del patrimonio», y después de aludir al principio de «subrogación real» en la glosa que realiza del artículo 93 del TRfdo.LS1976, puntualiza cómo «este artículo se limita a aplicar este elemental principio al establecer que los ingresos de las enajenaciones se destinarán "a la conservación y ampliación del mismo". El hecho de que figuren en el estado de ingresos del "presupuesto especial de urbanismo" los "productos de las enajenaciones de terrenos afectos al patrimonio municipal del suelo" no quiere decir que puedan destinarse a cubrir todos los gastos de ese presupuesto, que son los necesarios "para atender a las obligaciones derivadas de esta Ley". Sino que únicamente podrán destinarse al fin especifico del patrimonio municipal del suelo, que es más concreto. Por eso destacábamos la necesidad del reflejo presupuestario del destino de este patrimonio» ${ }^{34}$.

Los Profesores García de EnTERRÍA y PAREJo Alfonso, al referirse a la conformación del PMS como un patrimonio separado, coinciden también en afirmar que en «Derecho administrativo lo importante es la garantía de cumplimiento de un fin determinado (fin cuya vinculación determina la coherencia interna de los bienes incluidos en el patrimonio y su independencia externa para con respecto a cualquiera otros derechos $\mathrm{u}$ obligaciones de la misma persona)», y que «en el caso de los patrimonios públicos de suelo, su carácter de patrimonios separados es bien evidente, sobre todo por lo que hace a los municipales» ${ }^{35}$.

Desde la perspectiva dinámica de los PMS, los profesores de nuestra última referencia indican que «el producto de la enajenación de suelo no sale de la órbita del patrimonio...», y que «... el principio de subrogación real, esencial en esta institución (como en la doctrina civilista ha destacado ROCA SASTRE) y recogido expresamente en nuestro caso por el artículo 93 LS, conforme al cual «los ingresos obtenidos por la gestión urbanística mediante enajenación de terrenos del patrimonio se destinarán a la conservación y ampliación del mismo». De este modo puede decirse que las dotaciones económicas que se pongan a disposición del patrimonio municipal del suelo constituyen un fondo rotatorio de realimentación continua, por aplicaciones sucesivas al mismo fin, de dicho patrimonio, lo que constituye una técnica visible de potenciación financiera» ${ }^{36}$.

\footnotetext{
34 Jesús González Pérez, Comentarios a la Ley del Suelo, tomo I, cit., pp. 709-710.

35 E. García de Enterría y L. Parejo Alfonso, Lecciones de Derecho Urbanístico, cit., pp. 602-603.

${ }^{36}$ E. García de Enterría y L. Parejo Alfonso, Lecciones de Derecho Urbanístico, cit., p. 603.
} 


\subsection{La Ley 8/1990, de 25 de julio, de Reforma del Régimen urbanístico y Valoraciones del Suelo y su Texto Refundido}

\subsubsection{Los textos legales}

El preámbulo de la Ley 8/1990, de 25 de julio, de Reforma del Régimen urbanístico y Valoraciones del Suelo (LRU 1990), contiene las siguientes afirmaciones sobre «patrimonios públicos de suelo»:

- Incrementar «los patrimonios públicos de suelo en medida suficiente para incidir en la regulación del mercado inmobiliario o para adscribir superficies de suelo urbanizable a la construcción de viviendas de protección oficial» (punto I, último párrafo, inciso final).

- El fomento de «la constitución de patrimonios públicos de suelo, en concreto los de titularidad municipal, que son los únicos que se deben regular aquí, ya que las Comunidades Autónomas son competentes en lo relativo a su patrimonio respectivo y el del Estado tiene también su propia regulación» (punto VII, párrafo primero, inciso preliminar).

- «La potenciación de los patrimonios municipales de suelo no tiene un alcance meramente cuantitativo, sino también cualitativo, en cuanto al destino que a los mismos ha de darse... vinculados primordialmente a la construcción de viviendas de protección oficial u otras finalidades de interés social...» (punto VII, párrafo tercero).

La LRU 1990, dedica su Título VI al «Patrimonio Municipal del Suelo» (arts. 98-101), y de su Texto refundido aprobado por Real Decreto Legislativo 1/1992, de 26 de junio (TRfdo.LS1992), destacaremos sólo - como venimos haciendo a través de este trabajo - los aspectos más directamente relacionados, o mejor, que deben ser cuidadosamente diferenciados del de «afectación» de que nos ocupamos:

- Finalidad: «regular el mercado de terrenos, obtener reservas de suelo para actuaciones de iniciativa pública y facilitar la ejecución del planeamiento» (art. 276-1 TRfdo.LS1992).

- Afectación de terrenos: «los bienes del Patrimonio Municipal del Suelo constituyen un patrimonio separado de los restantes bienes municipales» (art. 276-2, inciso inicial, TRfdo.LS1992).

- Afectación de recursos: «los ingresos obtenidos mediante enajenación de terrenos o sustitución del aprovechamiento correspondiente a la 
administración por su equivalente metálico, se destinarán a la conservación y ampliación del mismo» (art. 276-2, inciso final, TRfdo.LS1992, de contenido sustancialmente idéntico a los arts. 76 LS1956 y 93 TRfdo.LS1976).

- Destino: «los bienes del Patrimonio Municipal del Suelo, una vez incorporados al proceso de urbanización y edificación, deberán ser destinados a la construcción de viviendas sujetas a algún régimen de protección pública o a otros usos de interés social, de acuerdo con el planeamiento» (art. 280-1, TRfdo.LS1992).

El artículo 276-1 TRfdo.LS1992 determinó que «deberán constituir su respectivo Patrimonio Municipal del Suelo» «los Ayuntamientos que dispongan de planeamiento general», modificando así, con este nuevo criterio, la anterior delimitación de Entidades municipales obligadas.

\subsubsection{La doctrina}

Esta continuidad en la normativa legal, no sólo sobre el principio de afectación de recursos de los PMS, sino también de los de finalidad de dichos patrimonios, de la afectación de terrenos (patrimonio separado), y de la determinación del destino de los subsodichos terrenos una vez que integren el tan repetido patrimonio, permite dar por válidos, sin reproducción expresa, todos los comentarios que la doctrina jurídico-administrativa ha realizado sobre la ya aludida «afectación de recursos», separándola y diferenciándola de los demás caracteres expuestos.

Los comentarios hechos por los expertos en Derecho administrativo en la materia que nos ocupa, con posterioridad a la STC 61/1997 y a las reformas urbanísticas de 1990 y 1992, abundan los mismos términos que han quedado reflejados en los epígrafes anteriores, referidos a las regulaciones precedentes.

Así, ciertos comentarios al TRfdo.LS1992, sin perjuicio de mantener la afectación de los recursos del PMS (enajenación de terrenos o sustitución de aprovechamiento) a la conservación y ampliación del mismo, hacen alusión a afirmaciones - muy contadas - que son de otra opinión, cerrando su exposición con la observación de que puede considerarse «una nueva situación de bienes muertos» «la permanencia indefinida en el patrimonio, sin incorporarse al proceso urbanizador», que puede producirse por el que denominan «principio de autofagia» del PMS (fondos 
rotatorios y cerrados) ${ }^{37}$, y que lo refieren a la determinación del «destino» de dicho patrimonio, y no a la aplicación de la regla de la «afectación de recursos».

El Profesor Francisco de Borja LÓPEZ-JuRADO Escribano dedicó todo un trabajo monográfico a los Patrimonios Municipales del Suelo ${ }^{38}$, donde - en síntesis - se argumenta contra la aplicación del principio de «subrogación real», tal como la doctrina mayoritaria ha venido entendiendo como explicación del deber de reinversión de los ingresos procedentes de la enajenación de los terrenos del PMS en gastos de conservación y ampliación, por entender que la «afectación a un fin» no precisa de dicha construcción jurídica y que son las finalidades fundamentales de dichos patrimonios (regular el mercado de terrenos, obtener reservas de suelo para actuaciones de iniciativa pública y facilitar la ejecución del planeamiento) las que condicionarán y limitarán el subsodicho deber de reinversión ${ }^{39}$.

La tesis del Profesor LóPEZ-JURADO ESCRIBANO, de negación del carácter de «patrimonio separado»-que denomina «patrimonio íntegro»- del PMS, cuyo deber de reinversión de los ingresos por enajenación de terrenos queda diluido, según una interpretación «amplia» de los fines de tal tipo de patrimonio, hasta poder desaparecer en la práctica, se apoya también en la institución presupuestaria. Así, bajo la vigencia de los Presupuestos especiales de Urbanismo, argumenta cómo éstos no contenían determinación de rúbrica específica en gastos para tales gastos de «conservación y ampliación», y que, después de la Ley 40/1981, con el nuevo Presupuesto «único» y la aplicación del principio de «unidad de caja», resultaba muy difícil mantener el principio de reinversión, pudiéndose considerar tales recursos subsumibles en la técnica contable de gastos con financiación afectada, consideraciones a las que había que agregar también lo que el autor expresa sobre diferenciación deletérea entre gastos corrientes y gastos de inversión ${ }^{40}$.

\footnotetext{
37 Francisco Lliset Borrell, José A. López Pellicer y Federico Romero Hernández, Secretarios de Administración Local, Ley del Suelo. Comentarios al Texto Refundido de 1992, tomo II, Publicaciones Abella, Madrid, 1993, pp. 634-637.

${ }^{38}$ Los Patrimonios Municipales de Suelo: sus caracteres y operatividad, INAP, CEMCI (Centro de Estudios Municipales y de Cooperación Interprovincial), Granada, 1992.

39 Los Patrimonios Municipales de Suelo: sus caracteres y operatividad, cit., pp. 37-39, 162-164, 167-174.

${ }^{40}$ Los Patrimonios Municipales de Suelo: sus caracteres y operatividad, cit., pp. 158-162, 164-166, 171-174.
} 
Entendemos que las razones de tipo presupuestario y contable alegadas en la monografía objeto de nuestro comentario no permiten servir de fundamento para las conclusiones a que el autor llega. En términos muy sintéticos estimamos que el deber de afectación (reinversión) de los recursos por enajenación de terrenos del PMS a gastos de conservación y ampliación del mismo, es un mandato legal, establecido por la legislación administrativa — en este caso la legislación de Suelo-, que tendrá su aplicación según los condicionamientos que la estructura presupuestaria de cada momento sea aplicable a las Entidades locales, y que al venir establecida normalmente por disposiciones reglamentarias, no pueden, en ningún caso, limitar, condicionar y menos suprimir una reinversión que está establecida por Ley.

Por otro lado, el principio de «unidad de caja» se refiere única y exclusivamente al aspecto de «gestión del presupuesto», que nada tiene que ver con la existencia o no, dentro de la propia LRHL o en otros sectores del ordenamiento jurídico, de afectaciones legales que han de ser cumplidas, fiscalizadas y, en su caso, revisadas también por los órganos de control externo. En este orden de ideas basta referirse a la técnica de remisión o reenvío utilizado por el artículo 146-2 LRHL, donde excluye el principio presupuestario de no afectación a aquellos «ingresos específicos afectados a fines determinados», determinación que puede encontrarse en cualquier ámbito del ordenamiento jurídico (en nuestro caso, repetimos, en la Ley del Suelo).

No obstante la singularidad de las tesis del Profesor LóPEZ-JuRAdO ESCRIBANO, afirma en los ámbitos del presupuesto y su gestión que «el deber de reinvertir... sólo puede ser incumplido si no se consignan en el Presupuesto de la Entidad local las cantidades cuyo destino sea la conservación o incremento del patrimonio municipal del suelo equivalentes a los ingresos que, teniendo su origen en la enajenación de bienes de dicho patrimonio, se esperan obtener o se han obtenido; o si no se realizan esos gastos» ${ }^{41}$, criterio, a nuestro parecer acertado, no admitido por la STS 2 noviembre 1995, pero sí por la Sentencia 718/1999, de 27 de abril, del Tribunal Superior de Justicia de Andalucía, pendiente de casación, de cuyo contenido se dará cuenta con posterioridad.

Pudiendo ser la «reinversión incondicionada», como el mismo autor dice, posible causa de consecuencias «del todo contrarias a la finalidad que anima la figura de los Patrimonios Municipales del Suelo», debién-

41 Los Patrimonios Municipales de Suelo: sus caracteres y operatividad, cit., p. 176. 
dose dar primacía a una interpretación amplia de la misma, que abogaría para que «se destinaran esos ingresos a otras inversiones en materia de urbanismo y vivienda», que debe dicha obligación «matizarse teniendo en cuenta el Plan General del Municipio», que el Programa Financiero del Presupuesto General de la Entidad local (art. 147-2 LRHL) no establece limitaciones sobre el destino previsto por cargas de urbanización y recursos patrimoniales ${ }^{42}$, y por la interpretación analógica del artículo 65 de la Ley del Suelo de 1990, le lleva a concluir que «una obligación incondicionada de reinversión de los frutos de las ventas de terrenos de esos patrimonios no es conforme con el marco normativo aplicable y puede implicar importantes desajustes e incongruencias» ${ }^{43}$.

El Profesor José Manuel DíAz LEMA, al estudiar el Texto Refundido de 1992, no obstante citar la opinión singular antes referida, defiende sin lugar a duda la afectación de los recursos del PMS (enajenación y aprovechamiento) a su conservación y ampliación, aludiendo explícitamente a los principios de «patrimonio separado» de los restantes bienes municipales y de «subrogación real» de sus recursos, pudiéndose sintetizar su clara posición cuando afirma que «la separación patrimonial contribuye decisivamente a evitar que el PMS pueda convertirse en una vía anómala de financiación de las Corporaciones locales, cautela más recomendable si cabe con la entrada en vigor de la nueva legislación, que permite incorporar al PMS suelo no urbanizable o urbanizable no programado» ${ }^{44}$.

Agustín Murillo CerRato, Interventor de Administración Local, mantiene de forma categórica la «afectación de recursos» del PMS (enajenación y aprovechamiento) a su conservación y ampliación, destacando, asimismo, la condición de "gastos con financiación afectada» que adquieren dichas atenciones dentro de la actual regulación presupuestaria y contable de las Haciendas locales ${ }^{45}$.

\footnotetext{
42 Discrepamos aquí también con el autor comentado, ya que, como hemos afirmado anteriormente, no tiene por qué la legislación presupuestaria en sentido estricto repetir o confirmar las posibles «afectaciones legales» de ciertos recursos a gastos determinados, que cualquier sector del ordenamiento jurídico pueda establecer.

${ }^{43}$ Los Patrimonios Municipales de Suelo: sus caracteres y operatividad, cit., pp. 179-180.

44 «El Patrimonio Municipal del Suelo en el Texto Refundido de 1992», en el Curso sobre el Texto Refundido de la Ley del Suelo de 26 de junio de 1992, Gerencia Municipal de Urbanismo, Ayuntamiento de Madrid, 1993, pp. 59-79; y también en Revista de Derecho Urbanístico, n. ${ }^{\circ}$ 136, año 1994, Editorial Montecorvo, pp. 13-50 (vid. especialmente pp. 64-65, en el Curso y pp. 23-25 en la Revista).

45 «Régimen económico, financiero y presupuestario de las Gerencias de Urbanismo», en la publicación Encuentro de Gerencias Municipales de Urbanismo, Gerencia Municipal de Urbanismo, Ayuntamiento de Madrid, 1994, pp. 105-115.
} 
El interesante trabajo del Profesor Ángel MenÉNDEZ ReXACH 46 trata, en términos generales, sobre la compatibilidad o congruencia de la regulación de los distintos patrimonios (especialmente los inmobiliarios) de las Administraciones públicas, al confrontarse los términos y sobre todo los efectos de la doble dicotomía dominio público-bienes patrimoniales e ingresos de Derecho público-Derecho privado, y asimismo la consideración de los diferentes aspectos «material» $\mathrm{y}$ «formal» de tales Administraciones y sólo contiene ciertas alusiones, bajo estas perspectivas, a los PMS.

A los efectos que ahora nos preocupan, puede afirmarse que no existe en dicho artículo alusión alguna, directa o indirecta, al tema de la afectación de recursos del PMS, a su conservación y ampliación, y sí a los de «destino» de los bienes que los integran, extremo sobre el que el autor insiste especialmente - dentro de una concepción finalista «amplia»-al considerar las exigencias del Estado social de Derecho referibles a dichos patrimonios separados de titularidad municipal, por tenerse que encauzar para atenciones «de interés social», y no otras, por relevantes o significativas que pudieran ser para los restantes objetivos de la gestión de las Entidades locales, y que sitúa a su régimen jurídico en las antípodas de su utilización con perspectivas de tipo lucrativo (concepción del patrimonio fiscal, según la terminología alemana acuñada) ${ }^{47}$.

En el estudio que estamos glosando, y aunque sólo podemos hacerlo de forma incidental, por no afectar plena y directamente al objeto de nuestra exposición, debemos manifestar nuestra discrepancia sobre la pretendida aplicación ambivalente que MENÉNDEZ REXACH atribuye a los «ingresos patrimoniales», ya que al tratar de la limitación del artículo 5 $L R H L$ de no poderse destinar los ingresos procedentes de la enajenación o gravamen de los bienes patrimoniales a la financiación de los «gastos corrientes», basándose, por un lado, en la que denomina «comunicabilidad entre los créditos de los Capitulos 2 y 6 , que permiten un amplio margen de maniobra al aplicar los respectivos conceptos presupuestarios», y por otro, en su inclusión en el Programa Financiero, del Plan de Inversiones [documento facultativo del Presupuesto General de las Entidades locales, según el art. 147-2-b) LRHL] ${ }^{48}$.

\footnotetext{
46 «Reflexiones sobre el significado actual de los patrimonios públicos», en Ciudad y Territorio, n. ${ }^{\text {ss }}$ 95-96, 1993, editada por el Centro de Publicaciones de la Secretaría General Técnica del Ministerio de Fomento, Madrid, pp. 209-221.

47 Ángel MenÉndez ReXach, «Reflexiones sobre el significado actual de los patrimonios públicos», cit., especialmente pp. 214-216, también en pp. 217 y 220.

48 Ángel Menéndez ReXach, «Reflexiones sobre el significado actual de los patrimonios públicos», cit., pp. 213-214.
} 
Nuestra disconformidad se basa — en términos extremadamente abreviados - en que dicho autor:

- Al referirse al artículo 5 LRHL está aludiendo a una de las «afectaciones legales de recursos a gastos de inversión», características de las Haciendas locales, en el supuesto concreto de enajenación o gravamen de bienes patrimoniales (que no sean parcelas sobrantes de la vía pública), y que han de canalizarse precisamente por el Capítulo 6, «Enajenación de inversiones reales», con aplicación al Capitulo 6, «Inversiones reales», que no tiene, en sentido técnico-presupuestario y contable estricto, ninguna comunicabilidad con el Capitulo 2, «Gastos en bienes corrientes y servicios», sino las que se puedan derivar, en la práctica, de las irregularidades (ilegalidades) que pueda cometer alguna Administración.

- Y respecto a la cita de los «recursos patrimoniales» del artículo 147-2-c) LRHL, deben entenderse, por el contexto en que se encuentran, que sólo hace referencia a los que tienen naturaleza de «ingresos de capital» que domina como género toda la enunciación de dicho precepto, y que por consiguiente son ingresos bien diferenciados y diferenciables de los que han de entenderse incluidos en el Capítulo 5, «Ingresos patrimoniales».

El publicista Esteban CORRAL GARCíA, Secretario de Administración Local, recuerda cómo la institución del $P M S$ constituyó un rotundo éxito en Alemania y en Suecia, pero «en España constituyó un rotundo fracaso, no tuvo la más mínima eficacia y muchos Ayuntamientos se convirtieron en especuladores necesarios para sufragar el estado calamitoso de las arcas municipales», y al referirse a los Presupuestos especiales de Urbanismo concreta cómo los «ingresos (5 por 100 del Presupuesto Ordinario y los procedentes de ventas de terrenos) finalistas fueron desnaturalizados, pues por un lado las adquisiciones de suelo lo fueron de terrenos necesarios para obras o servicios municipales y las obras de urbanización no fueron realmente tales, sino mera ejecución de obras ordinarias de urbanización» ${ }^{49}$, observaciones críticas que también explicita al tratar de los Presupuestos especiales de Urbanismo bajo la Ley de Suelo de 1976, cuando afirma que «... sus Presupuestos arrastraban una debilidad rayana en la miseria...» y que «si algún terreno o solar de inventario (Patrimonio Municipal del Suelo) se vendía, su producto no era reinvertido en terrenos, sino que venía a sufragar las "obras ordinarias», disculpando o demorando la transferencia del 5 por 100 del Presupuesto Ordinario

49 «El Patrimonio Municipal del Suelo», Revista El Consultor de los Ayuntamientos, n. ${ }^{\circ}$ 9, Madrid, 15 de mayo de 1994, pp. 1171-1189 (vid. p. 1172). 
al Especial de Urbanismo. Por todo ello, su desaparición (la del Presupuesto Especial) no molestó a nadie ni provocó protesta alguna» ${ }^{50}$.

El autor citado - CORRAL GARCÍA - también suscribe la naturaleza de «patrimonio separado» del PMS, por ser un «patrimonio especial», adscrito a «un fin específico primordialmente», y «constituye una masa patrimonial que se transforma de cosa en dinero, y viceversa, gira en torno de sí mismo, es una masa que está continua y constantemente en movimiento, por lo que en teoría se financia por sí mismo, su objeto específico lo es el suelo» ${ }^{51}$.

Al referirse tanto a la $L R U 1990$ como al TRfdo.LS1992 afirma cómo parten «de un principio ampliamente generoso de potenciación y ampliación del Patrimonio Municipal del Suelo y de un criterio restringido en cuanto a la limitación de los fines», lo que no obsta para que continúe afirmando, al referirse a la gestión de los PMS, que «... por lo general, el Patrimonio Municipal del Suelo es una pura entelequia. Todos los bienes que legalmente lo integran o deben integrarlo aparecen diluidos dentro del Patrimonio e Inventario General del Ayuntamiento. En definitiva, y hasta la fecha, casi ninguna Corporación o Ayuntamiento conoce su Patrimonio Municipal del Suelo. Hora es de que se haga y confeccione un Inventario separado o diferenciado del General, aunque integrado en él», para cuya tarea aboga por «un adecuado tratamiento informático» 52 .

En las conclusiones de su trabajo, el publicista CORRAL GARCÍA indica cómo «el adecuado funcionamiento del Patrimonio Municipal del Suelo exige de las Corporaciones Locales una gran capacidad de gestión de la que carecen», ya que «su lentitud e ineficacia no es precisamente alentadora. Hace falta un gran aparato técnico-burocrático y, sobre todo, recursos, muchos recursos, de los que se carece. Ello dará lugar a una aplicación mediocre, parcial y cómoda, reducida a la que provoque la iniciativa privada en las cesiones...», por lo que finaliza afirmando que «la nueva Ley vitaliza instituciones fracasadas en España: Patrimonio del Suelo y Derecho de Superficie y otras que con análogas regulaciones han fracasado en el extranjero. Con una Administración inoperante, falta de medios y escasamente rigurosa en el gasto, el porvenir no parece brillante, sino más bien nublado» ${ }^{53}$.

\footnotetext{
50 Esteban Corral García, «El Patrimonio Municipal del Suelo», cit., p. 1174.

51 Esteban Corral García, «El Patrimonio Municipal del Suelo», cit., p. 1173.

52 Esteban Corral García, «El Patrimonio Municipal del Suelo», cit., p. 1188.

53 Esteban Corral García, «El Patrimonio Municipal del Suelo», cit., p. 1189.
} 
La monografía de Fernando E. FONSECA FERRANDIS trata incidentalmente el tema objeto de nuestra atención cuando se refiere al «destino» de los PMS ${ }^{54}$.

El referido autor indica que el fundamento del PMS como «un patrimonio separado y afectado a la gestión urbanística» $\mathrm{y}$, por tanto, distinto del «patrimonio ordinario de la Corporación local», se puede justificar en un triple orden de causas 55 :

- Punto de vista económico: «permite su financiación a través de la reinversión sucesiva de los rendimientos obtenidos con su gestión».

- Perspectiva jurídica: «garantizar el destino de dicho patrimonio».

- Gestión: «cierta especialización y, por tanto, una autonomía organizativa, presupuestaria y patrimonial».

En el trabajo de FonSECA FERRANDIS se habla de las distintas causas que han determinado el «fracaso» de los PMS, insistiendo al mismo tiempo que, «en general, se pueden reconducir a la ausencia de los medios jurídicos adecuados para obligar a los Ayuntamientos a gestionar correctamente sus patrimonios de suelo» ${ }^{56}$, y al estudiar el «destino» de dichos patrimonios, en lo que denomina concepciones «amplia»o «estricta» de su «carácter finalista», resume su posición respecto de la primera - defendida sólo por dos autores, según su exposición - al decir que «aceptar esta posición significa volver a la situación anterior a la Reforma de 1990, puesto que la intención del legislador de potenciar cualitativamente los Patrimonios Municipales del Suelo queda vacía de contenido» ${ }^{57}, \mathrm{y}$ por lo que hace referencia a la concepción «estricta» puntualiza que «en definitiva, la finalidad genérica del Patrimonio Municipal es la intervención en el mercado inmobiliario y, en general, facilitar la ejecución del planeamiento. Ahora bien, esta finalidad se concreta, una vez que los bienes integrados en este patrimonio se incorporan al proceso de urbanización y edificación, mediante su aplicación a dos usos específicos, es de-

\footnotetext{
${ }^{54}$ El régimen jurídico de los patrimonios municipales del suelo, Universidad Carlos III de Madrid-Boletín Oficial del Estado, Madrid, 1995 (Capítulo IV, «El destino del patrimonio municipal del suelo», pp. 117-145).

${ }^{55}$ Fernando E. FonseCa FerRandis, El régimen jurídico de los patrimonios municipales del suelo, cit., p. 117.

${ }^{56}$ El régimen jurídico de los patrimonios municipales del suelo, cit., p. 121.

${ }^{57}$ El régimen jurídico de los patrimonios municipales del suelo, cit., p. 123.
} 
cir, la construcción de viviendas sujetas a algún régimen de protección pública o su afectación a otros usos de interés social» ${ }^{58}$.

El mismo comentarista de la legislación del suelo de que estamos haciendo cita, al referirse a lo que denomina «instrumentos contables»y después de recordar la concepción de los PMS como fondos rotatorios de retroalimentación continua mediante la aplicación sucesiva de sus rendimientos a la gestión urbanística, afirma literalmente: «Debido a la inexistencia de un aparato contable que permita diferenciar entre el patrimonio ordinario de la Corporación y el patrimonio separado, la única garantía que permite asegurar que estas cantidades son aplicadas a la ampliación y conservación de aquel patrimonio municipal, como exige el Texto Refundido, es la creación de un órgano desconcentrado - Gerencia de urbanismo - con el fin de gestionar el Patrimonio Municipal del Suelo. Éste debe contar en el presupuesto único de la Corporación local con una sección presupuestaria especial o apéndice propio. En el caso de que se le haya dotado de personalidad jurídica, ha de contar con un presupuesto propio que se debe unir al presupuesto general de la Corporación. Estas secciones presupuestarias deben reflejar las diferentes partidas de ingresos y gastos correspondientes a la gestión del Patrimonio Municipal del Suelo. Recordemos para finalizar que la obligación de realizar estas previsiones presupuestarias puede, incluso, ser exigida judicialmente por los ciudadanos a través de la acción popular» 59 .

Fernando GARcía FlóREz, Secretario de Administración Local, se adscribe a la doctrina mayoritaria sobre la calificación de «patrimonio separado», respecto del PMS, en el que actúa el principio de «subrogación real» e «integridad patrimonial», así como la consideración de dicho patrimonio como "fondo rotatorio de realimentación continua», y reconociendo con la práctica totalidad de la doctrina el amplio incumplimiento normativo respecto de dichos patrimonios por los Ayuntamientos, expresa su opinión de que de los obstáculos antes existentes subsisten el de «falta de atractivo para los políticos, porque los frutos del Patrimonio Municipal del Suelo se recogen a largo plazo» y el de «la mayor complejidad de la gestión del Patrimonio Municipal del Suelo como lógica consecuencia de la diversidad de sus bienes integrantes y formas de adquisición», por lo que su operatividad «dependerá fundamentalmente de la voluntad política de los gobernantes de cada momen-

\footnotetext{
58 El régimen jurídico de los patrimonios municipales del suelo, cit., p. 127.

59 El régimen jurídico de los patrimonios municipales del suelo, cit., p. 145.
} 
to, pues la nueva Ley potencia desde luego la institución y facilita los recursos para su constitución y ampliación» ${ }^{60}$.

El publicista Paulino Martín HeRnÁndez, Adjunto a la Secretaría General del Ayuntamiento de Madrid, tiene publicado un breve trabajo sobre el «destino» de los bienes del PMS ${ }^{61}$, en donde sienta sus tesis sobre lo que denomina su «destino amplio» y los «destinos específicos», ámbitos sobre los que no incide el objeto de este trabajo, como hemos puntualizado desde el inicio del mismo, y por lo que no nos pronunciamos en este momento, debiendo significar, no obstante, que no participamos en buena parte de las afirmaciones que el referido autor hace para - a su criterio - extender las finalidades de tales patrimonios municipales dentro de la órbita de su «destino amplio».

La brevísima alusión que hace a la «afectación de recursos del PMS para su conservación y ampliación» la enmarca en un epígrafe que denomina «límites a la flexibilidad del destino de los patrimonios municipales del suelo», donde después de aludir, en primer lugar, al «planeamiento», dice literalmente: «En segundo lugar, y derivada de su naturaleza de patrimonio separado (art. 276.2 T.R.L.S.), surge la exigencia de que "los ingresos obtenidos mediante enajenación de terrenos o sustitución de aprovechamiento por su equivalente metálico, se destinarán a la conservación y ampliación del mismo". Ésta es una razón más para defender el destino genérico de este Patrimonio, porque en los casos de enajenación de bienes, siempre que sea para las finalidades legales, los productos de los mismos seguirán estando integrados en la masa patrimonial, es decir, no se produce merma alguna de la misma», expresión ambigua y falta de la más mínima congruencia dentro del lugar «sistemático» del trabajo, ya que para el supuesto que cita del artículo 276-2 TRfdo.LS1992, «las finalidades legales» no son sino las de «conservación y ampliación [del PMS]», que acababa de transcribir en este pequeño párrafo, no pudiéndose deducir de su literalidad — transcrita íntegramente — una defensa de la tesis de poder utilizar tales productos de la enajenación o de los aprovechamientos medios en usos dotacionales y otras finalidades urbanísticas, como el citado publicista ha mantenido posteriormente en otro ámbito.

\footnotetext{
60 «Nuevas perspectivas del Patrimonio Municipal del Suelo: régimen jurídico aplicable. Su instrumentalidad técnica», Revista El Consultor de los Ayuntamientos, n. ${ }^{\circ}$ 22, Madrid, 30 de noviembre de 1995, vid. especialmente pp. 3003-3007 y 3025.

61 «El destino de los bienes integrados en el patrimonio municipal del suelo», Análisis Local, n. ${ }^{\circ} 6$ (mayo-junio 1996), Ed. Consultores de las Administraciones Públicas, Madrid, pp. 9-17.
} 
Los Profesores Tomás QuinTANA LóPEZ y J. Miguel LoBATO GóMEZ, al tratar la naturaleza jurídica y carácter de patrimonio separado del PMS, afirman que «... el artículo 276.2 del texto refundido urbanístico vigente asume la categoría dogmática del patrimonio separado y dispone que "los bienes del Patrimonio Municipal del Suelo constituyen un patrimonio separado de los restantes bienes municipales y los ingresos obtenidos mediante enajenación de terrenos o sustitución del aprovechamiento, correspondiente a la administración por su equivalente en metálico, se destinarán a la conservación y ampliación del mismo", por lo que esa condición y las consecuencias jurídicas de la misma ya son incontestables» 62 .

Tras referirse a la «subrogación real» del producto obtenido de la gestión por enajenación del Patrimonio Municipal del Suelo, y con alusión al mismo artículo 276-2 TRfdo.LS1992, sostienen: «... en definitiva, se advierte una voluntad clara del legislador, seguramente dirigida a favorecer el progresivo incremento del patrimonio municipal del suelo, pero también dispuesta a impedir que este instrumento se convierta en fuente de financiación de los municipios», siendo por tanto exigible «una interpretación estricta del artículo 276-2 in fine de ese texto legal que impida cubrir con los ingresos procedentes de la enajenación de terrenos del patrimonio municipal del suelo otras necesidades presupuestarias del municipio...» ${ }^{63}$.

\subsubsection{Resoluciones jurisdiccionales sobre «afectación legal de recursos del PMS»}

a) Sentencia del Tribunal Supremo de 2 de noviembre de 1995

La Sentencia del Tribunal Supremo de 2 de noviembre de 1995, de la Sala 3. ${ }^{\text {a }}$, Sección 5. ${ }^{\text {a }}$, de lo Contencioso-Administrativo (Aranzadi de 1995, referencia 8.060), resolviendo Recurso de Apelación contra la Sentencia del Tribunal Superior de Justicia del País Vasco de 22 de diciembre de 1990, sobre acuerdos de 1986 del Ayuntamiento de Vitoria-Gasteiz, en relación con la venta de trece parcelas-solares del Patrimonio Municipal del Suelo, para aplicación parcial a las atenciones explicitadas en

\footnotetext{
62 Tomás Quintana López y J. Miguel Lobato Gómez, La constitución y gestión de los Patrimonios Municipales del Suelo, Marcial Pons, ediciones Jurídicas y Sociales, S. A., Madrid, 1996, p. 36 .

${ }^{63}$ Quintana López, Lobato Gómez, La constitución y gestión de los Patrimonios Municipales del Suelo, cit., p. 37.
} 
Autos y provenientes de un expediente de suplemento de crédito, y en relación con el tema objeto de este trabajo - la afectación legal de recursos por enajenación de terrenos del PMS a su conservación y ampliación (art. 93 TRfdo.LS1976, en las actuaciones, equivalente al 276-2, inciso final, TRfdo.LS1992, ahora vigente)—, fija las siguientes afirmaciones, de meridiana rotundidad:

- «El Patrimonio Municipal del Suelo fue regulado en la Ley del Suelo de 1956 como un conjunto de bienes de que las Corporaciones se pueden servir "para regular el precio en el mercado de solares" (Exposición de Motivos), con la finalidad de "prevenir, encauzar y desarrollar técnica y económicamente la expansión de las poblaciones". Este conjunto de bienes tiene una característica especial, a saber, que su finalidad especifi$c a$ se realiza mediante la circulación propia del tráfico jurídico, pero sin disminución o merma del propio Patrimonio, toda vez que el producto de las enajenaciones de los bienes de éste habrá de destinarse a la conservación y ampliación del propio Patrimonio (artículo 93 del TRLS). Por ello se ha podido decir que "las dotaciones económicas que se pongan a disposición del Patrimonio Municipal del Suelo constituyen un fondo rotatorio de realimentación continua, por aplicaciones sucesivas al mismo fin de dicho Patrimonio, lo que constituye una técnica visible de potenciación financiera". En definitiva, se ha venido así aceptando pacíficamente que el Patrimonio Municipal del Suelo constituye un "patrimonio separado" (lo que hoy está ya expresamente dicho en el artículo 276.2 del nuevo Texto Refundido de la Ley del Suelo de 26 junio 1992 [RJ 1992, 1.468]). La Ley ha querido y quiere que el Patrimonio Municipal del Suelo funcione como un patrimonio separado, es decir, como un conjunto de bienes afectos al cumplimiento de un fin determinado, fin que aquí no es cualquiera de los que las Corporaciones han de perseguir según la legislación de Régimen Local (artículos 25 y 26 de la Ley de Bases de Régimen Local de 2 abril 1985 [RCL 1985, 799, 1.372 y ApNDL 205]), sino el especifico y concreto de "prevenir, encauzar y desarrollar técnica y económicamente la expansión de las poblaciones" (artículo 89.2 del Texto Refundido de 9 abril 1976), y ha querido y quiere expresamente con una claridad elogiable que el producto de las enajenaciones de terrenos del Patrimonio se destinen no a cualquier fin, por loable y razonable que sea, sino al específico de la conservación y ampliación del propio Patrimonio Municipal del Suelo (artículo 93, ya citado)» (Fundamento Jurídico Octavo).

- «Ésta es la caracterización que el legislador ha dado a los Patrimonios Municipales del Suelo, y se comprenderá que, ante tamaña claridad, 
sólo una expresa previsión legislativa en contrario puede hacer que los mismos, abandonando su origen, su caracterización y su finalidad, pasen a convertirse en fuente de financiación de otras y muy distintas necesidades presupuestarias municipales. Esto, desde luego, puede hacerlo el legislador (asumiendo el posible riesgo de desaparición de los Patrimonios Municipales del Suelo), pero no puede hacerse por la vía de la interpretación sociológica de las normas jurídicas (artículo 3.1 del Código Civil), porque esa interpretación ha de respetar, en todo caso, el espiritu y la finalidad de las normas, muy otras, como hemos visto, a la financiación general e indiscriminada de las necesidades municipales» (Fundamento Jurídico Noveno).

La referida Sentencia del Tribunal Supremo, entre otras precisiones, alude - en su Fundamento Jurídico Sexto- a que los acuerdos que pueden ser impugnados son los que afectan, no al Presupuesto o al expediente de suplemento de crédito, sino los que materializan la «ejecución del Presupuesto» (decisión de venta en pública subasta), y que la naturaleza y caracterización de los Patrimonios Municipales del Suelo como «patrimonio separado» no pueden ser variados por el Plan General, ni por la adquisición con exceso de patrimonio por parte de los Ayuntamientos, ante «una norma tan clara y concluyente como la que contiene el artículo 93 del TRLS» (Fundamento Jurídico Décimo).

Las precisiones realizadas en la Sentencia de nuestra referencia, cuyo contenido principal acabamos de transcribir, han sido tenidas en cuenta, hasta el momento, por otras Sentencias posteriores de Tribunales Superiores de Justicia, aunque la tercera de las que vamos a hacer alusión se distancia - a nuestro criterio de forma muy positiva - de la postura del TS de considerar no impugnable el Presupuesto (sus consignaciones de ingresos $\mathrm{y} / \mathrm{o}$ de gastos).

b) Sentencias de Tribunales Superiores de Justicia

En este sentido, la Sentencia del Tribunal Superior de Justicia de Castilla y León número 227/1999, de 9 de marzo (Sala de lo Contencioso-Administrativo, Sección Única), sobre el acuerdo del Ayuntamiento de Segovia aprobando definitivamente el Presupuesto General para el ejercicio de 1997, recoge en su Fundamento Jurídico Cuarto la doctrina de la STS de 2 de noviembre de 1995, sobre la «afectación legal de recursos del PMS», resolviendo que el recurso interpuesto «no puede ser objeto de consideración con ocasión de la aprobación de un Presupuesto... sin perjuicio de que en su día pueda recurrirse por este motivo a la enajena- 
ción de dichos solares si el destino que se atribuye al montante obtenido es diferente a lo señalado por el precepto alegado».

También la Sentencia del Tribunal Superior de Justicia del País Vasco número 394/1999, de 7 de mayo (Sala de lo Contencioso-Administrativo, Sección 1.a), resolviendo recurso contra el acuerdo plenario del Ayuntamiento de Hernani de 18 de noviembre de 1996, aprobando expediente de habilitaciones de créditos, anula el acuerdo por lo que se refiere a la consignación de un millón y medio de pesetas para adquisición de una ambulancia, afirmando en su Fundamento Jurídico Tercero «... la necesidad de que los ingresos obtenidos con la enajenación de los bienes que forman parte del PMS reviertan al mismo...».

La Sentencia del Tribunal Superior de Justicia de Andalucía número 718/1999, de 27 de abril (Sala de lo Contencioso-Administrativo), en recurso interpuesto contra el acuerdo plenario del Ayuntamiento de Almería de 30 de diciembre de 1995, aprobando definitivamente su Presupuesto General para 1996, tomando una posición completamente diferente a la de las resoluciones jurisdiccionales antes mencionadas, anula por contrario a Derecho dicho Presupuesto, indicando expresamente en su Fundamento Jurídico Quinto: «En el presente caso el examen de los apartados de los Presupuestos relativos a ingresos por enajenación de inversiones reales y al anexo de inversiones financiadas con cargo al capítulo anterior evidencia que gran parte de los ingresos a obtener por venta de solares, que integran por disposición legal el Patrimonio Municipal del suelo del Ayuntamiento de Almería, tenían como destino la financiación de inversiones a realizar con fines públicos distintos al de conservación o ampliación de dicho Patrimonio, y por ende debe incluirse que tal desviación incurre en clara ilegalidad, viciando de anulabilidad dichos Presupuestos».

\subsubsection{La STC 61/1997, de 20 de marzo}

La falta de discusión previa con las autoridades autonómicas y locales, así como con los operadores públicos y privados, hizo que la LRU 1990 fuera «mal recibida por todos y provocó la reacción de las Comunidades Autónomas, una parte de las cuales la impugnó ante el Tribunal Constitucional, impugnación a la que luego se acumuló la del Texto Refundido subsiguiente de 26 de junio de 1992, dando así lugar finalmente a la espectacular Sentencia constitucional de 20 de marzo de 1997, que hizo saltar por los aires, roto en mil pedazos, el ordenamiento urbanístico al anu- 
lar, por razones estrictamente competenciales, más de doscientos artículos del citado Texto Refundido» ${ }^{64}$.

Los preceptos anteriormente transcritos del TRfdo.LS1992, que hacen referencia a los PMS, regulando su finalidad (art. 276-1), la afectación de terrenos (art. 276-2, inciso inicial), la afectación de recursos (art. 276-2, inciso final) y a su destino (art. 280-1), han sido declarados subsistentes - con el carácter de legislación básica- por la STC 61/1997, de 20 de marzo (Pleno) en los Recursos de inconstitucionalidad acumulados números 2477, 2479, 2481, 2486, 2487 у 2488/1990, 2337, 2341 у 2342/1992 65, extremo que ha ratificado, asimismo, la Ley 6/1998, de 13 de abril, sobre Régimen del Suelo y Valoraciones, en su disposición derogatoria única, punto $1 .^{\circ}$

\subsubsection{La doctrina más reciente}

Miguel Aguinaga MarTínez se fija fundamentalmente en los aspectos propios de la fiscalización de las materias de urbanismo, de ahí su insistencia en los enfoques de tipo presupuestario. Al tratar de la «reinversión del producto de la enajenación del Patrimonio Municipal del Suelo» sitúa con más precisión el alcance de esta «afectación legal de recursos», tanto al referirse a que tales recursos deban entenderse no sólo como ingresos realizados, sino también como pendientes de realización (en realidad «derechos contraídos»), para rectificar, en tal sentido, las alusiones - frecuente entre los administrativistas - de la referencia al «dinero» como elemento integrante del PMS, alusión totalmente alejada de la perspectiva presupuestaria que hay que conectar a los créditos y a los débitos.

También matiza el mismo autor que la referida afectación de recursos del PMS no cabe encuadrarla única y exclusivamente dentro del mandato del artículo 5 de la $L R H L$, que excluye la aplicación de los ingresos por enajenación o gravamen de bienes patrimoniales a los «gastos corrientes», ya que entre los «gastos de conservación» del PMS caben los de naturaleza «corriente», recordando las dificultades que existen para el análisis presupuestario de tales atenciones, sobre todo por dos razones, la primera por ser el «ciclo» de la gestión urbanística normalmente más extenso que el del ejercicio anual presupuestario, y la segunda porque ni

\footnotetext{
${ }^{64}$ Tomás-Ramón Fernández Rodríguez, Manual de Derecho Urbanístico, 13. ${ }^{a}$ edición, Publicaciones Abella, Madrid, 1998, p. 40.

${ }^{65}$ Publicada en el suplemento del BOE n. ${ }^{\circ}$ 99, de 25 de abril de 1997, y en el BJC (Boletín de Jurisprudencia Constitucional de Cortes Generales), n. ${ }^{\circ}$ 192, de abril 1997, pp. 14-151.
} 
la clasificación «económica» ni la clasificación «funcional» permiten diferenciar los gastos en relación con su afectación al Patrimonio Municipal del Suelo, por lo que la verificación, objetiva, debe hacerse con cada uno de los datos presupuestarios desagregados y con los expedientes individualizados de gestión urbanística ${ }^{66}$.

El Secretario de Administración Local y conocido publicista en materias de Derecho urbanístico José Luis GONZÁLEZ-BERENGUER URRUTIA, en un reciente trabajo y con ocasión de tratar el PMS en relación con la oferta de suelo en mano pública, por haberse ideado tales patrimonios como mecanismos de intervención en el mercado de suelo para conseguir, entre otros objetivos, su abaratamiento, se pregunta sobre la «coherencia legislativa», así como el «aspecto ético» de las posibles enajenaciones de suelo, a precio de mercado (o, al menos, a precio superior del de adquisición por expropiación), que pueden constituir «fuente de financiación» del urbanismo, pero no contribuir al abaratamiento pretendido del suelo, y en este ámbito hace una amplia referencia a la Sentencia del Tribunal Supremo (de lo Contencioso-Administrativo) de 2 de noviembre de 1995, antes acotada, que hay que entender asume en líneas generales, ya que, prácticamente, transcribe sus Fundamentos Jurídicos esenciales, sin crítica alguna ${ }^{67}$.

Los Consultores de Administraciones Públicas, además de ratificar que «el producto de la realización de terrenos del PMS o el equivalente en efectivo de la cesión del aprovechamiento debe ser destinado por el Ayuntamiento a la conservación y ampliación del PMS», presentan una evolución de los ingresos por enajenación de inversiones (Porcentajes 1984-1994, Derechos reconocidos 1987-1994), así como de los ingresos patrimoniales (Derechos reconocidos 1987-1994), datos que varían sensiblemente según la base de población relativa, pero que en definitiva y en términos generales demuestran el valor «más bien marginal» de dichos recursos y que por consiguiente «el urbanismo no es ni mucho menos una vía de recursos sensible para los Ayuntamientos, por lo que poco puede hacer para paliar la penuria financiera de éstos». Y por lo que se refiere a la «reforma legislativa» — referida a la fecha de este trabajo-, destacan «la urgente necesidad de modernizar las estructuras de gestión

\footnotetext{
${ }^{66}$ Miguel Aguinaga Martínez, Jefe del Departamento de Intervención de Urbanismo y Obras del Ayuntamiento de Madrid, «Fiscalización en materia de urbanismo», en el Curso sobre El control interno en las Corporaciones Locales, Servicio de Publicaciones Diputación de Castellón, 1997 (vid. especialmente pp. 235-236, 239-241, 245-246).

${ }^{67}$ La Financiación del urbanismo y el precio de los terrenos, Colección Autonómica y Local, editorial Montecorvo, S. A., Madrid, 1997, pp. 233-239.
} 
y financiación de los Ayuntamientos, que son piezas esenciales para el funcionamiento eficiente del sistema urbanístico» ${ }^{68}$.

La monografía del Profesor Salvador María MARTín VALDIVIA acentúa desde sus principios el «espíritu instrumental y finalista» del PMS, sobre el que hace girar todo su trabajo — en realidad tesis doctoral — y reconoce, con la doctrina más usual, que «no obstante las medidas innovadoras recogidas en la Ley del Suelo de 1975, el tiempo ha vuelto a confirmar la escasa importancia práctica que los Patrimonios Municipales del Suelo obtuvieron en sus quince años de vigencia; por ello la Ley del Suelo 1990 ha acudido de una forma casi desesperada en pos de la salvación definitiva de esta institución...», insistiendo también en que «... se venía haciendo de forma sistemática caso omiso a la exigencia del artículo 93 [Ley del Suelo 1975] (los ingresos obtenidos para la gestión urbanística mediante enajenación de terrenos del patrimonio se destinarán a la conservación y ampliación del mismo»), y se utilizaban los ingresos generados por el patrimonio para sufragar gastos ordinarios del maltrecho presupuesto municipal... hoy en día el problema del control de esa desviación presupuestaria se ha elevado a límites inusitados...» ${ }^{69}$.

En el trabajo de referencia se dedica un amplio espacio a glosar la Sentencia del Tribunal Supremo de 2 de noviembre de 1995, donde se recogen parte de las tesis, con su respectiva cita, de las realizadas en su día por el Profesor LÓPEZ-JURADO ESCRIBANO, siendo de gran interés el siguiente apartado: «... la verdadera fundamentación de esta resolución judicial que analizamos, que no responde sino a la imperiosa necesidad — que en la generalidad de los casos se impone - de frenar las tendencias abiertamente "desviadas" de los Ayuntamientos españoles. Quizá la Corporación que ha servido como "cobaya" para esta sentencia ejemplarizante no haya sido, por sus peculiaridades urbanísticas, la más idónea. Aun así, se advierte con claridad cuál es la última ratio de la resolución analizada: el T.S. ha querido poner coto a la tendencia especulativa actual de la inmensa mayoría de los Ayuntamientos españoles que pretenden canalizar - a través de la explotación de los bienes que debían de integrar el Patrimonio Municipal del Suelo- las vías de obtención de recursos que palien los déficit generados por el presupuesto ordinario cuando no es ese el fin que el legislador ha querido para tales bienes. Y ciertamente esa admonición no debe caer en saco roto, pero entendemos que el Alto Tri-

\footnotetext{
${ }^{68}$ Ignacio Ezquiaga Domínguez, José María Ezquiaga Domínguez, «Urbanismo y Haciendas Locales», Análisis Local, n. ${ }^{\circ}$ 12, mayo-junio 1997, pp. 7-11.

${ }^{69}$ Urbanismo y especulación: los Patrimonios Públicos del Suelo, editorial Montecorvo, S. A., Madrid, 1998, pp. 29, 60 y 63.
} 
bunal se ha excedido en la tarea ejemplificadora exigiendo para todos los Ayuntamientos del territorio nacional la implantación del rígido sistema de retroalimentación obligada que en muchos casos puede resultar exorbitante» ${ }^{70}$.

En realidad, toda la crítica a la referida Sentencia del Tribunal Supremo, que va delimitando la tesis del autor que comentamos, se puede resumir en que acusa a la misma de falta de «flexibilidad» y que «ha renunciado a sentar una doctrina interpretativa definitiva de la figura estudiada, puesto que si bien pretende advertir a los Ayuntamientos acerca de lo que no deben hacer en politica municipal de suelo, no termina de ser determinante al respecto de lo que sí deben impulsar a ese respecto» ${ }^{71}$.

El Profesor Fernando E. FonseCA FERRANDIS, al estudiar los PMS 72, recuerda el carácter de «patrimonios separados y afectados a un determinado destino: la gestión urbanística...», así como la obligación de reinvertir constituyendo «un fondo rotatorio de retroalimentación continuo por aplicaciones sucesivas al mismo fin..., circunstancia que ha sido puesta de relieve por el artículo 276-2 TRLS92...», aspecto de «los ingresos patrimoniales obtenidos con la gestión del correspondiente patrimonio de suelo», en el que alude a la doctrina unánime de mayor calificación en el Derecho administrativo (GARCÍA DE ENTERRÍA y PAREJO ALFOnSO, PÉREZ Moreno o GonZÁlez PÉREZ) ${ }^{73}$.

En el estudio del Profesor Julio V. GonZÁLez GARCÍA se abunda en los mismos conceptos y determinaciones, con referencia idéntica a la legislación vigente, por lo que excusamos su transcripción ${ }^{74}$.

\footnotetext{
70 Salvador María Martín Valdivia, Urbanismo y especulación: los Patrimonios Públicos del Suelo, cit., pp. 199-217 (vid. p. 207).

${ }^{71}$ Salvador María Martín Valdivia, Urbanismo y especulación: los Patrimonios Públicos del Suelo, cit., pp. 212-217 (vid. p. 216).

72 «Intervención Pública en el Mercado del Suelo» (Capítulo X de la obra colectiva Derecho Urbanístico de la Comunidad de Madrid, Instituto Pascual Madoz del Territorio, Urbanismo y Medio Ambiente, Universidad Carlos III de Madrid, Marcial Pons, Ediciones Jurídicas y Sociales, S. A., Madrid-Barcelona 1998), vid. apartado VI, «Los patrimonios públicos de suelo», pp. 401-413.

${ }^{73}$ Fernando E. Fonseca Ferrandis, «Intervención Pública en el Mercado del Suelo», cit., pp. 402-403 y 406 .

74 «La intervención pública en el mercado del suelo en la legislación urbanística de la Comunidad de Madrid» (Capítulo Decimoquinto de la obra colectiva El Derecho Urbanistico en la Comunidad de Madrid, Editorial Lex Nova, Valladolid, 1999), vid. apartado IV, «Patrimonios públicos del suelo», pp. 426-430.
} 
El Secretario de Administración Local Fernando RodRIGO MoRENO tiene un interesante artículo, que el propio autor indica en su inicio «no tiene en absoluto carácter doctrinal», pero que por su experiencia contiene afirmaciones de especial interés. Así, al referirse al que denomina «sistema cerrado de autoalimentación establecido en el Patrimonio $\mathrm{Mu}-$ nicipal del Suelo en el artículo 276-2 de la Ley del Suelo de 1992», dice que «merece la crítica más radical, pues supone que todo ingreso obtenido de la enajenación de inmuebles del Patrimonio Municipal del Suelo ha de afectarse exclusivamente a la conservación y ampliación de éste...» ${ }^{75}$.

En el mismo trabajo, no obstante lo reseñado anteriormente, afirma rotundamente: «... una interpretación supuestamente flexible del artículo 276.2 mencionado, que permita entender que "conservación y ampliación" del patrimonio municipal del suelo equivale a cualquier inversión de índole urbanística, me parece francamente ilegal porque las palabras que la Ley emplea son inequívocas y su intención también», por lo que añade su posición a favor de la Sentencia de la Sala de lo Contencioso-Administrativo del Tribunal Superior de Justicia de Andalucía de 27 de abril de 1999, de la que hemos dejado reseña anteriormente, y que declaró nulo el Presupuesto del Ayuntamiento de Almería para el ejercicio de $1996^{76}$.

La Profesora Fátima CASTILlo Gómez indica cómo el PMS «es un instrumento por el que han apostado todas las legislaciones urbanísticas, desde la LS56 hasta nuestros días. A pesar de que su aplicación práctica ha sido siempre escasa», lo que no obsta para que entienda que «un funcionamiento serio de este instituto jurídico es una de las mejores cosas que puede hacer el municipio por sus habitantes» ${ }^{77}$.

En su trabajo subraya cómo los artículos 276.1 y 280.1 TRfdo.LS1992 han creado «unos serios anclajes acerca de los fines y destino de dicho instituto jurídico» y que «el elemento finalista tiene gran importancia... como una de las técnicas de control de las potestades discrecionales de la Administración», consideraciones que le llevan a referirse a la STS de 2 de noviembre de 1995, sobre venta de parcelas-solares del PMS del

\footnotetext{
75 «Tres problemas urbanísticos: integración de los edificios en el Patrimonio Municipal del Suelo, destino de los bienes integrantes de este Patrimonio y extensión subjetiva de la carga real en el sistema de compensación», El Consultor, n. ${ }^{\circ}$ 6, 30 de marzo de 2000, Madrid, pp. 997-1002 (vid. p. 1000).

${ }^{76}$ Fernando Rodrigo Moreno, «Tres problemas urbanísticos..., cit., p. 1000.

77 «Los Patrimonios Municipales del Suelo: destino y finalidad», El Consultor, n. ${ }^{\circ} 21,15$ noviembre 2000, Madrid, pp. 3478-3489 (vid. pp. 3478-3479).
} 
Ayuntamiento de Vitoria, a la que hemos dedicado un epígrafe específico, ultimando su exposición con una esperanza a que «fructifique y arraigue» el instituto de los PMS, dada la potenciación que intentan darle las legislaciones autonómicas, a pesar de que «una de las principales causas de la hasta ahora mala aplicación de estos patrimonios municipales del suelo ha sido la utilización por los Municipios de éstos para especular, y no para destinarlos a sus finalidades auténticas. Los Municipios llegan al efecto perverso de encarecer los suelos públicos con el actual sistema de subasta que recalientan el mercado...» ${ }^{78}$.

En un trabajo monográfico muy reciente, orientado principalmente hacia los aspectos económicos, presupuestarios y contables de los PMS, se continúa insistiendo sobre el escaso éxito de su constitución y la incorrecta aplicación de sus fondos, según la normativa del suelo. Así, se afirma que tales PMS se han convertido en «un mecanismo extraordinario de financiación, las más de las veces para un uso diferente del legalmente previsto», y que «esta distorsión del uso previsto por la Ley para los patrimonios municipales del suelo constituye una de las expresiones de su fracaso como instrumento de intervención administrativa en el mercado del suelo a la vez que prueba palpable de la insuficiencia del sistema de financiación de las Entidades Locales», siendo el carácter restrictivo respecto a sus posibilidades de uso «una invitación a la vulneración de tales restricciones para atender necesidades más perentorias desde el punto de vista de la gestión política» ${ }^{79}$.

El autor del referido trabajo estudia la obligación de reinversión del artículo 276-2 TRfdo.LS1992, el carácter de patrimonio separado del PMS y la aplicación del principio de subrogación, hace una amplia referencia a la STS de 2 de noviembre de 1995, y después de criticar la ubicación de los ingresos sustitutivos del aprovechamiento, en el Capítulo 3 (Tasas y otros ingresos), del estado de ingresos ${ }^{80}$, debiendo ser la del Capítulo 6 (Enajenación de inversiones reales) - tesis que compartimos totalmente-, alude cómo pueden convertirse «las tesorerías de muchos Ayuntamientos españoles en una especie de "agujero negro", en el que ha desaparecido una buena parte del patrimonio municipal del suelo que deberían haber acumulado a lo largo de años de gestión urbanística» y que,

\footnotetext{
${ }^{78}$ Fátima Castillo Gómez, «Los Patrimonios Municipales del Suelo: destino y finalidad», cit., pp. $3480-3481$ y 3489 .

79 José-Ignacio Martínez García, Aspectos Económicos y Tributarios del Urbanismo, Editorial BAYER Hermanos, S. A., Barcelona, 2001, pp. 97-98.

${ }^{80}$ Según consulta 9/1993, evacuada por la IGAE.
} 
desde el punto de vista presupuestario y contable, si la reinversión no se ha producido antes de finalizar el ejercicio, se debe «proceder a realizar los ajustes del resultado presupuestario y del remanente de tesorería precisos» ${ }^{81}$.

Los textos más recientes de Derecho urbanístico, al referirse a la «afectación legal de recursos del PMS» establecida en el artículo 276-2 del TRfdo.LS1992, hacen referencia a todos los conceptos ya aludidos en este trabajo, y acuñados por la doctrina general jurídico-administrativa, abundan sobre la exigencia estricta de la subsodicha afectación, sin confundirla con «la finalidad» de dicho patrimonio separado (art. 276-1 TRfdo.LS1992), ni tampoco con el «destino» de los bienes ya integrados en el mismo (art. 280-1 TRfdo.LS1992) y, además, citan normalmente la Sentencia del Tribunal Supremo de 2 de noviembre de 199582.

\section{LA AFECTACIÓN LEGAL DE RECURSOS DE LOS PMS COMO NORMA DE ACCIÓN}

\subsection{Normas de relación y normas de acción}

La doctrina jurídico-administrativa ha recogido la influencia, sobre todo italiana, para diferenciar en dos grandes grupos las normas aplicables a los distintos actos y resoluciones de las Administraciones públicas en relación con los administrados.

Así, el Profesor Fernando GARRIDO FALLA, al tratar dentro de «las situaciones jurídicas subjetivas» los «intereses legítimos y los derechos subjetivos debilitados», literalmente expone: «Resulta de aquí que del examen del conjunto de normas que constituyen el Derecho administrativo aparece la existencia de dos clases distintas: unas, que han sido dictadas previamente para garantizar, frente a la actividad administrativa, situaciones jurídicas individuales; otras, que no han sido dictadas con esta finalidad, sino fundamentalmente para garantizar una utilidad pública. GUICCIARDI llama a las primeras normas de relación y a las segundas normas de acción. Estas últimas se refieren a la organización, al conteni-

\footnotetext{
81 José-Ignacio Martínez García, Aspectos Económicos y Tributarios del Urbanismo, cit., pp. 105-110.

82 Tomás-Ramón Fernández Rodríguez, Manual de Derecho Urbanístico, 15. a edición, Publicaciones Abella, Madrid, 2000, p. 150. Ricardo Estévez GoYTRe, Manual de Derecho Urbanístico, Editorial Comares, S. L., Granada, 2001, p. 400; Ricardo Santos Diez, Julio Castelao Rodríguez, Derecho Urbanístico, 4. ${ }^{\text {a }}$ edición, El Consultor, Madrid, 2001, pp. 928-932 y 933-934.
} 
do y al procedimiento que ha de presidir la acción administrativa; imponen, por tanto, una conducta obligatoria a la Administración, pero tal obligación no se corresponde con el derecho subjetivo de que sean titulares unos determinados particulares [La giustizia amministrativa, 2. ${ }^{\mathrm{a}}$ edición, pp. 8 a 15]. Claro es que cualquiera podría alegar su interés en que tales normas de acción sean respetadas por la acción administrativa; pero sería éste un interés vago e impreciso, que por no estar protegido por el ordenamiento jurídico se conoce con el nombre de simple o mero interés» ${ }^{83}$.

En términos equivalentes, el Profesor Eduardo GARCÍA DE ENTERRÍA, al estudiar los derechos subjetivos y legalidad de la Administración, expone: «... la doctrina italiana va a entrar en un esfuerzo constructivo verdaderamente notable, lleno de sutileza, para precisar la figura jurídica de los llamados "intereses legítimos" por diferencia de la tradicional de los derechos subjetivos... Una segunda explicación creerá encontrar la clave en la naturaleza puramente procesal del interés legítimo, que sería una simple "proyección procesal del interés de facto", identificándolo de hecho con la legitimación para recurrir. En fin, GUICCIARDI ha puesto en circulación otra explicación que presenta, por de pronto, el mérito de la simplicidad: el derecho subjetivo aparece en la actividad administrativa producida bajo la regulación de "normas de relación" intersubjetiva; en cambio, el interés legítimo sería el correlato de una actuación de la Administración producida bajo el imperio de "normas de acción", que pautan tal actuación desde una perspectiva única del interés público, sin intentar construir relaciones jurídicas»» ${ }^{84}$.

En relación con la obligación por parte de los Ayuntamientos de constituir sus respectivos PMS, y dentro de esta clasificación normativa que se ha dejado reseñada, es de todo punto conveniente recordar una de las afirmaciones realizadas por nuestra doctrina administrativa que, a pesar de haber sido hecha durante la vigencia de la LS 1956, es perfectamente trasladable a nuestro momento actual, «... las obligaciones legales, sobre todo cuando sólo son exigibles por acciones populares, quedan incumplidas cuando falta la voluntad de darlas cumplimiento...» ${ }^{85}$.

\footnotetext{
83 Tratado de Derecho Administrativo, vol. I (Parte General), 12. ${ }^{\text {a }}$ ed., Tecnos, S. A., Madrid, 1994, p. 387.

84 Eduardo García de Enterría, Tomás-Ramón Fernández Rodríguez, Curso de Derecho Administrativo, vol. II, 6. ' edición, Editorial Civitas, Madrid, 1999, p. 42.

85 José María Boquera Oliver, «El patrimonio municipal de suelo», cit., p. 210.
} 
Dentro de una referencia más amplia, que afecta a buena parte del contenido del Derecho financiero, cabe pensar en el estudio sobre los principios de legalidad material y no meramente formal aplicables al «gasto público», como mandatos dirigidos a las Administraciones públicas, calificables como «normas de acción», y sobre las que la doctrina ha insistido en la búsqueda de soluciones jurídicas, al margen de las de tipo jurisdiccional, basadas en medidas como la distribución de competencias, funcionamiento de los órganos, controles internos, y otras, que son las que pueden influir en la realización de tales mandatos legales que no encuentran un titular de derecho subjetivo, que, motivado por ese interés directo, pueda ejercitar las acciones administrativas y jurisdiccionales de impugnación de los actos ilegales o irregulares de la actividad administrativa ${ }^{86}$.

\subsection{La impugnación de los Presupuestos de las Entidades locales}

Suprimida la tutela administrativa respecto de la aprobación de los Presupuestos de las Entidades locales, a partir del Real Decreto-Ley 3/1981, de 16 de enero, tramitado y convertido posteriormente en Ley 40/1981, de 28 de octubre, de Medidas sobre Régimen Jurídico de las Corporaciones Locales ${ }^{87}$, actualmente sólo cabe hablar de «reclamaciones» en vía administrativa sobre su aprobación inicial (arts. 150-1 y 151 LRHL) y de «recurso contencioso-administrativo» contra los aprobados definitivamente (art. 152-1 LRHL).

Considerando como motivo de reclamación o recurso contra un Presupuesto municipal cualquier incumplimiento respecto de la «afectación legal de recursos» del PMS a los gastos de conservación y ampliación del mismo (art. 276-2 TRfdo.LS1992), y que puede afectar tanto a los ingresos como a los gastos respectivos, $\mathrm{y}$, asimismo y simultáneamente, a dichas dos facetas o vertientes presupuestarias, nuestro Derecho positivo permite, al declarar los legitimados respectivos, que tanto en la vía de reclamación administrativa (art. 151 LRHL) como en la de recurso contencioso-administrativo [art. 19 de la Ley 29/1998, de 13 de julio, Reguladora de la Jurisdicción Contencioso-Administrativa (LJ)], puedan actuar los que ostenten «interés legítimo».

\footnotetext{
86 Álvaro Rodríguez BereiJo, Introducción al Derecho Financiero, Instituto de Estudios Fiscales, Ministerio de Hacienda, Madrid, 1976, pp. 99-110.

${ }^{87}$ Esta medida fue mucho más allá de lo que se precisó en la Sentencia del Tribunal Constitucional de 2 de febrero de 1981, que admitió la perfecta compatibilidad entre «autonomía local» y tutela de tipo administrativo «de legalidad» sobre los Presupuestos locales, extremo que subsiste en ordenamientos locales comparados. Vid. a este respecto Vicente J. Arnau Bernia, Manual de Presupuestos de las Entidades Locales, cit., pp. 83-86 y 103-107.
} 
El incumplimiento por parte de los Ayuntamientos de sus deberes respecto a los PMS, en general, y a la afectación legal de recursos, en particular, de los que se hacen eco prácticamente todos los autores que han tratado estas materias, contrasta con la casi inexistente conflictividad jurisdiccional respecto de tales cuestiones, que sólo tienen su explicación en la consideración — antes hecha— de que las normas sobre tales obligaciones impuestas a las Entidades municipales no son sino «normas de acción», que no configuran ni amparan ningún derecho subjetivo o interés directo.

Las escasas resoluciones jurisdiccionales conocidas hasta el momento avalan las afirmaciones anteriores y, además, sirven para poner más de relieve cómo la instancia jurisdiccional contencioso-administrativa, por su tardanza en obtener la Sentencia definitiva y firme, supone ya de por sí una dudosa solución para una situación - sobre terrenos y actuaciones municipales sobre ellos- que no pueden diferirse o dilatarse por períodos tan amplios sin desnaturalizar tanto la situación inicial corporativa como la final de la resolución del Tribunal correspondiente, y que tan sólo mediante una pervivencia - admitida en el Derecho local comparado- de algunas tutelas de tipo administrativo sobre la aprobación de los Presupuestos de las Entidades locales podrían, quizá, evitar estos perniciosos resultados y, posiblemente, conseguir un mejor cumplimiento de las obligaciones impuestas por este tipo de «normas de acción».

No abundamos sobre el tremendo daño que supone para el Estado de Derecho - $\tan$ llevado y traído últimamente de forma generalmente trivial - la existencia de estas normas, que se saben incumplidas por amplios ámbitos administrativos (en este caso por las Administraciones municipales) por la subsodicha falta de tutela administrativa de tipo externo, y la inoperancia - en casos como el estudiado - tanto del control interno como del control externo.

Ante un incumplimiento normativo de lo dispuesto en el artículo 276-2 TRfdo.LS1992 por parte de una Administración municipal, y no obstante el informe negativo que haya podido ser emitido por el órgano de control interno (Intervención) de la legalidad económico-financiera y presupuestaria, según el artículo 149-4 LRHL, de no actuarse por algún «interesado» (miembro corporativo de los grupos en oposición, particulares y asociaciones o entidades), dicho control interno no se encuentra habilitado específicamente, como quizá debiera serlo, para interponer el correspondiente recurso contencioso-administrativo, o, al menos, elevar a otra instancia gubernativa o de control externo (central o autonómica) la cuestión para su conocimiento y actuaciones posteriores pertinentes. 
Sin embargo, la legislación vigente no permite tales soluciones, ya que el sistema de impugnación de actos y acuerdos de las autoridades locales (arts. 63-68 LBRL) se formula como «mera posibilidad» (art. 65 LBRL), y se centra fundamentalmente en que afecten o no a las competencias de las autoridades superiores, estatales o autonómicas (art. 66 LBRL), o que atenten gravemente el interés general de España (art. 67 LBRL).

El órgano de control externo (Tribunal de Cuentas) tampoco puede actuar de oficio en estos supuestos y, teniendo en cuenta que en la mayor parte de los casos correspondientes al incumplimiento del artículo 276-2 TRfdo.LS1992, puede producirse una falta de «nivelación presupuestaria», en la medida que la previsión de los ingresos por enajenación o aprovechamientos de terrenos del PMS no se dediquen a los correspondientes gastos de conservación y ampliación del mismo, sino a otros, incluso de otro carácter urbanístico, tan sólo intervendrá emitiendo informe, en su caso, si existiere recurso contencioso-administrativo contra el Presupuesto definitivo (art. 152-2 LRHL).

El ámbito estrictamente jurisdiccional en que queda la contienda sobre el posible incumplimiento de la afectación legal de recursos del PMS, con el más que dilatado período de tiempo que requiere su solución definitiva, explica, en parte, sin olvidar el amplísimo incumplimiento de dicha legislación, la exigüidad de contiendas de tipo contencioso planteadas hasta el momento durante los cuarenta y cinco años de «vigencia» (¿teórica?) de dicho mandato.

\subsection{Impugnación de los actos de gestión del PMS}

El tan repetido incumplimiento normativo del artículo 276-2 TRfdo.LS1992 por parte de las Administraciones municipales se expresa o puede visualizarse, en primer término, con ocasión de la tramitación y votación del Presupuesto General de las Entidades locales, planteando el problema de las reclamaciones o recursos, respectivamente, sobre la aprobación inicial o definitiva de dicho documento presupuestario, extremo sobre el que nos hemos referido anteriormente.

Sin embargo, repetimos, y dado nuestro sistema vigente de falta de tutela financiera de tipo administrativo sobre aprobación de presupuestos de las Entidades locales, de impugnabilidad de sus actos y acuerdos, y de configuración de las facultades de los órganos de control interno (Intervención de las Entidades locales) y externo (Tribunal de Cuentas), cabe plantearse la continuidad de dicho incumplimiento normativo sobre la 
afectación de recursos del PMS, en vía de gestión del Presupuesto, ya que, además de la falta de solución a un informe negativo por parte del órgano de control interno, con ocasión de la tramitación y aprobación del mismo, cabe que dicha infracción se plantee estrictamente como derivada de un acto de gestión, al acordar la enajenación de terrenos del PMS que puedan considerarse «un nuevo ingreso» que dé lugar a un crédito extraordinario o suplemento de crédito (art. 158-1-4 LRHL), o a una generación de crédito [art. 162-b) LRHL].

Aunque la situación partiera de la gestión presupuestaria, sin antecedente correlativo en el Presupuesto, las dificultades para la efectividad práctica de un posible «reparo de legalidad» por parte del órgano de control interno (Intervención de la Entidad local) son prácticamente las mismas que se han analizado anteriormente.

Si el reparo afectara a la vertiente de los ingresos (enajenación de terrenos), en virtud del artículo 197-1 LRHL, «en ningún caso suspenderá la tramitación del expediente», pero en realidad la consideración propia de este recurso (ingreso), por su caracterización legal de estar «afectado» a unos gastos concretos y determinados (conservación y ampliación del PMS), lleva a que no pueda ser calificado sólo desde esta perspectiva, sino la de su referencia obligada al gasto que debe existir ya en el Presupuesto inicial, o acordarse simultáneamente, cuando menos, con el correspondiente expediente de modificación de los créditos de gasto, lo que lleva directamente a un reparo en el gasto, que sí tiene carácter suspensivo, por ubicarse bien en la omisión en el expediente de «requisitos o trámites esenciales», según el artículo 197-2-c) LRHL (los créditos de gasto para conservación y ampliación del PMS) o por encuadrarse en la falta de crédito «adecuado», según el artículo 197-2-a) LRHL.

De no admitirse por la Presidencia de la Corporación local la discrepancia que pudiera presentarse ante los reparos de la Intervención (art. 198-1 LRHL), la esterilidad de estos últimos se produciría, de no ser impugnados en vía contencioso-administrativa por algún miembro de la Entidad local que no haya votado a favor de tales acuerdos o por cualquier administrado, casos posibles, pero que en la práctica resultan ser contadísimos, dada la falta de legitimación del órgano de control interno para realizar tal impugnación, y de la ausencia de mecanismos de comunicación o traslado de tales reparos hacia órganos externos (administrativos o de control), como anteriormente también dejamos subrayado. 


\section{LA AFECTACIÓN LEGAL DE RECURSOS DEL PMS EN EL PRESUPUESTO DE LA GERENCIA MUNICIPAL DE URBANISMO DE MADRID}

\subsection{Antecedentes}

La Gerencia Municipal de Urbanismo de Madrid (GMUM) fue creada según lo dispuesto en el artículo 17-1 de la Ley 121/1963, de 2 de diciembre, sobre el Área Metropolitana de Madrid (LAM) y el Reglamento del Área Metropolitana de Madrid (RAM), aprobado por Decreto 3088/ 1964, de 28 de septiembre (Ministerio de la Vivienda) (BOE n. ${ }^{\circ} 245$, de 12 de octubre de 1964; corrección de errores en $B O E$ números 250 y 260, de 17 y 29 de octubre de 1964), mediante acuerdo del Ayuntamiento Pleno de fecha 27 de noviembre de 1964.

Los Presupuestos de la GMUM se derivan de la personalidad jurídica que le reconoció a dicho Ente institucional del Ayuntamiento de Madrid la LAM y el RAM, antes citados.

Desde 1981, año en que finalizaron los tradicionales «Presupuestos especiales de Urbanismo», los Presupuestos de la GMUM, con grandes oscilaciones interanuales, abarcan no sólo la «gestión urbanística» en sentido estricto, entendiendo como tal sólo la preparación del suelo para su utilización según las determinaciones del planeamiento y mediante los sistemas de actuación previstos en la legislación urbanística, sino también - de facto - otras realizaciones propias de la actividad inversora municipal general, recogiendo de tal forma, y de modo indebido, atenciones que deberían figurar en el Presupuesto del Ayuntamiento de Madrid.

El mandato contenido en el artículo 276-2 TRfdo.LS1992, sobre afectación legal de recursos del PMS, había venido siendo observado y cumplido tanto en los Presupuestos de la GMUM como en su gestión presupuestaria y en la liquidación de los mismos.

Corroboración concreta y específica de esta afirmación se encuentra en la Liquidación del Presupuesto de la GMUM del ejercicio de 1998, en que se produjo un exceso de financiación de ingresos del PMS, por importe de 3.995,7 millones de pesetas, dando lugar a una afectación de parte del Remanente de Tesorería a la financiación de gastos destinados a la conservación y ampliación de dicho Patrimonio, objeto de seguimiento y control durante 1999 y cuyo sobrante no utilizado en dicho ejercicio se continuó atribuyendo por importe de 1.799 millones de pesetas al PMS para el ejercicio 2000 . 
También confirma este acatamiento normativo el que, durante el ejercicio 2000, una modificación del Presupuesto de la GMUM, aprobada por el Ayuntamiento Pleno el 26 de octubre de dicho año, se hizo con el informe de Intervención General que ponía de manifiesto la incidencia negativa que en la afectación de recursos del PMS suponía la baja por anulación en partidas de gasto destinadas al mismo y la aplicación de mayores ingresos por venta del suelo, siendo el importe total de ambos conceptos 1.906,8 millones de pesetas, debiéndose afectar en el momento de la liquidación la parte necesaria del Remanente Líquido de Tesorería que en aquel momento (31 diciembre 2000) resultara un exceso de financiación de los recursos del tan repetido PMS.

\subsection{Presupuesto de la GMUM de 2001}

La Intervención General del Ayuntamiento de Madrid emitió su informe preceptivo, según se determina en el artículo 149-4 de la LRHL y en el artículo 18-4 del Reglamento Presupuestario (RP), aprobado por Real Decreto 500/1990, de 20 de abril, del Ministerio de Hacienda, conteniendo la protesta de no haber podido utilizar el plazo de diez días, mínimo, para su formulación, dadas las circunstancias de urgencia con que se presentó la documentación correspondiente.

El informe de Intervención sobre el proyecto de Presupuesto General para 2001 fue emitido el 11 de noviembre de 2000 y, por lo que se refería al de la GMUM, daba cuenta de la infracción del artículo 276-2 TRfdo.LS1992, ya que los gastos de conservación y ampliación del PMS eran de 12.505,4 millones de pesetas, inferiores a los ingresos vinculados a dicho fin, por importe de 23.100 millones de pesetas.

La Comisión Informativa extraordinaria de Hacienda, Economía y Comercio, celebrada el día 13 de noviembre de 2000, dictaminó dicho proyecto de Presupuesto, con el solo informe, aludido, de la Intervención General, anunciándose verbalmente, por el Quinto Teniente de Alcalde (Rama de Hacienda, Personal y Régimen Interior), la confección de otro informe en la GMUM.

Como consecuencia de la citada reunión de la Comisión Informativa aludida y habiéndose modificado la cifra de gastos, antes determinada, a un nuevo importe de 11.781,5 millones de pesetas, por variaciones introducidas por los órganos de gestión en esas fechas, que producían en definitiva, según los datos presupuestarios, un exceso de financiación afectada de 11.318,5 millones de pesetas, extremos que se concretaron en el informe de Intervención de 15 de noviembre de 2000. 
En ambos informes de la Intervención General, emitidos y comunicados con anterioridad a la sesión plenaria municipal extraordinaria (de aprobación inicial del Presupuesto General para 2001), se hacía un detallado estudio de los datos económicos del proyecto de Presupuesto de la GMUM para 2001, de la normativa de suelo vigente, de la Sentencia del Tribunal Supremo de 2 de noviembre de 1995 (Contencioso-Administrativo. Sala Tercera. Sección Quinta; Aranzadi: ref. 8060), que claramente exigía la afectación legal de recursos por enajenación de terrenos del PMS a los gastos de conservación y ampliación del mismo, insistiéndose también en la precedente actuación de dicha Gerencia urbanística en el sentido de respetar y acatar hasta el ejercicio de 2000 dicho mandato legal.

En la sesión extraordinaria celebrada por el Ayuntamiento Pleno el día 16 de noviembre de 2000, se aludió por el Quinto Teniente de Alcalde (Rama de Hacienda, Personal y Régimen Interior) a un informe de la Dirección de Servicios de la Secretaría Jurídica de la GMUM, y de acuerdo con el mismo se votó por mayoría la aprobación inicial del Presupuesto de la GMUM para 2001, no obstante los dos informes desfavorables emitidos por el órgano de control interno (Intervención General).

No habiendo sido conocido el referido informe de la Dirección de Servicios de la Secretaría Jurídica de la GMUM ${ }^{88}$ por la Intervención General hasta el día 20 de noviembre de 2000 , y en virtud de su petición expresa por escrito, se realizó un nuevo informe por esta Dependencia de control interno, con fecha 29 de noviembre de 2000 , en el que se aludía al tan repetido informe de la GMUM, mostrando su total disconformidad con el mismo, y abundando en los aspectos ya tratados en los informes anteriores, con una cita amplia de la doctrina jurídico-administrativa (urbanística), expresada, en términos esquemáticos, sobre la afectación legal de recursos del PMS.

En la Comisión Informativa de Hacienda, Economía y Comercio, celebrada el 18 de diciembre de 2000, para el dictamen sobre aprobación definitiva del Presupuesto General para el 2001, el Quinto Teniente de Alcalde (Rama de Hacienda, Personal y Régimen Interior) solicitó informe a la Secretaría General sobre el Presupuesto de la GMUM.

\footnotetext{
${ }^{88}$ Dicho informe, fechado el 10 de noviembre de 2000, lleva un «conforme» del Secretario General de fecha 16 del mismo mes, donde, en síntesis, se subsume —y más diríamos, se confunde - el tema del «destino» de los bienes del PMS con el de la afectación de recursos de dicho patrimonio, según el artículo 276.2 TRfdo.LS1992.
} 
Como consecuencia de dicha Comisión Informativa, la Intervención General emitió un nuevo informe, el cuarto de los relacionados con el Presupuesto de la GMUM para 2001, que concluyó el día 20 de diciembre de 2000, víspera de la fecha de celebración del Pleno — 21 diciembre 2000 - para la aprobación definitiva del Presupuesto General para 2001, en el que se abundaba también en el Derecho urbanístico de la Comunidad Autónoma de Madrid, en la doctrina jurídico-administrativa más reciente y en el carácter del informe de la Intervención General sobre los Presupuestos.

El Secretario General ultimó también su informe, solicitado por la Quinta Tenencia de Alcaldía, el mismo día 20 de diciembre de 2000, que no fue conocido por el Interventor General hasta media hora antes de iniciarse el plenario municipal ${ }^{89}$.

Por mayoría de votos, el Ayuntamiento Pleno, en su sesión de 21 de diciembre de 2000, y basándose en los informes de la Dirección de Servicios de la Secretaría Jurídica de la GMUM y de la Secretaría General, aprobó el Presupuesto General para 2001, incluyendo el de la GMUM en los términos y determinaciones numéricas que había sido objeto de cuatro informes desfavorables de la Intervención General, por infracción del deber de afectación legal de recursos del Patrimonio Municipal del Suelo a los gastos de su conservación y ampliación, según prescribe el artículo 276-2 TRfdo.LS1992.

Teniendo en cuenta la falta de conocimiento previo por parte de Intervención General, con el tiempo suficiente para realizar un informe con anterioridad a la aprobación definitiva del Presupuesto General para 2001, es por lo que con posterioridad a la correspondiente sesión plenaria se emitió un nuevo informe por la Dependencia responsable del control interno, con fecha 27 de diciembre de 2000, donde se hacía un resumen de las circunstancias — de todo género- que habían rodeado el trámite presupuestario, en lo referente a la GMUM y donde se ratificaba en todos sus informes anteriores, se mostraba la disconformidad total con el informe de la Secretaría General y como se salía al paso de la posible o pretendida «neutralización» de la función de control por parte del Quinto Teniente de Alcalde, solicitando informe a la Secretaría General, abundan-

\footnotetext{
89 El informe del Secretario General partía de la no diferenciación entre el «destino» de los bienes ya incluidos en el PMS (art. 280.1 TRfdo.LS1992) y la «afectación legal de recursos por enajenación de terrenos» (art. 276.2 TRfdo.LS1992), o como se decía en el mismo su «puesta en relación», alejándose también, por consiguiente, de la casi totalidad de la doctrina jurídico-administrativa urbanística, que no incurre en dicha confusión.
} 
do también en que el problema del incumplimiento - tan repetido- del artículo 276-2 TRfdo.LS1992 no quedaba zanjado con la aprobación definitiva del Presupuesto, ya que la Intervención General debería formular los reparos de legalidad pertinentes durante la gestión de la GMUM, cuando y respecto de los actos administrativos, concretos y determinados, que materializaran el incumplimiento del deber de afectación legal de recursos del PMS a gastos de su conservación y ampliación.

Al margen de otras muchas precisiones y comentarios que podrían y deberían seguir a las actuaciones antes reseñadas, sólo en sus aspectos esenciales y de forma muy esquemática, y que abundaron en detrimento de las facultades legales de la Intervención General, es patente la irregularidad total del procedimiento, donde los informes preceptivos de la Intervención General sobre el Presupuesto de la GMUM se quisieron neutralizar mediante los insólitos informes de la Secretaría Jurídica de la GMUM y de la Secretaría General del Ayuntamiento, insertándolos en el expediente sin conocimiento previo y tiempo suficiente para que el órgano de control interno pudiera aludir a los mismos, circunstancias que obligaron - como se ha visto - a emitir informes con posterioridad a los plenarios municipales de la aprobación provisional y la aprobación definitiva ${ }^{90}$, actuación que si no se sitúa completamente, sí que se aproxima extraordinariamente a un supuesto de «desviación de poder».

\section{RECAPITULACIÓN}

- El mandato legal de afectación de recursos se mantiene, en lo fundamental, prácticamente invariado desde su formulación inicial (art. 76 LS1956), continuando, con identidad total, en la primera modificación (art. 93 TRfdo.LS1976), y manteniéndose esencialmente el mismo en su última concreción (art. 276-2 TRfdo.LS1992), que únicamente añade la «sustitución del aprovechamiento correspondiente a la administración por su equivalente metálico».

- Dicha afectación ha sido diferenciada, en la legislación del suelo:

Del destino de sus terrenos (art. 280-1 TRfdo.LS1992)

De la finalidad de dichos patrimonios (art. 276-1 TRfdo.LS1992).

- El artículo 276-2 TRfdo.LS1992, precepto donde se establece la afectación legal de recursos del PMS, ha sido declarada legislación bási-

${ }^{90}$ Informes de Intervención General: tercero, de 29 de noviembre de 2000, y quinto, de 27 de diciembre 2000. 
ca según la STC 61/1997, de 20 de marzo, por lo que resulta una materia que deben acatar y que no pueden legislar sobre la misma las Comunidades Autónomas.

- La doctrina administrativa mayoritaria, pudiéndose hablar por tanto de una doctrina común o general:

Ha estudiado con mayor amplitud todo el régimen jurídico relacionado con el «destino» de los bienes y la «finalidad» de los PMS, aludiendo sólo de pasada a la «afectación de recursos».

Ha diferenciado cuidadosamente los tres caracteres aludidos del régimen jurídico del PMS, siendo manifiestamente minoritaria la postura que aboga en otra dirección.

Ha enfatizado la naturaleza de patrimonio separado del PMS, que en su redacción del TRfdo.LS1992 (art. 276-2, primer inciso) ya se inserta como Derecho positivo, la obligación de reinversión de los fondos obtenidos por la gestión urbanística y la consiguiente constitución de un fondo rotatorio de realimentación continua.

Últimamente también ha insistido sobre el carácter de legislación básica del artículo 276-2 TRfdo.LS1992.

- La doctrina jurídico-administrativa en el ámbito urbanístico, más cercana a nuestros días, continúa recordando y puntualizando la estricta obligación legal de la afectación de recursos del PMS (por enajenación y aprovechamiento de sus terrenos), a cuyo efecto cabe recordar:

- Los trabajos de los Secretarios de Administración Local, que, no obstante todas sus consideraciones de matiz e incluso críticas, mantienen la exigencia indubitada del mandato legal de nuestra referencia.

- Los textos generales de Derecho urbanístico, que singularizan el tratamiento específico de esta afectación de recursos del PMS y que, por tanto, no permite hablar propiamente de «jurisprudencia», resulta PMS, sin dejar de citar, normalmente, la STS de 2 de noviembre de 1995.

- La doctrina jurisdiccional, muy escasa, pero muy clara y terminante respecto de la obligación legal de afectación de recursos del PMS, y así:

- La STS de 2 de noviembre de 1995 califica de norma clara y concluyente el mandato que actualmente se contiene en el artículo 276-2 TRfdo.LS1992, excluyendo que por una pretendida «interpretación so- 
ciológica» se pueda dejar de respetar el espiritu y finalidad de las normas y que el incumplimiento de dicho deber de reinversión propicie una indebida y prohibida financiación general e indiscriminada de las necesidades municipales, subrayando de forma expresa y concreta al carácter de patrimonio separado del PMS y sus dotaciones económicas, aludidas, como fondo rotatorio de realimentación continua.

- La STS de 2 de noviembre de 1995 estima, por el carácter de mera previsión que tienen los estados de ingresos de los Presupuestos de las Entidades locales, que las impugnaciones contra la obligación legal de afectación de recursos del PMS no puedan ser estimadas en el momento de su aprobación, o de la de sus expedientes de modificación de créditos, debiendo quedar aplazada su admisión contra los actos concretos de gestión, extremo que no consideramos el más adecuado para garantizar el interés legítimo que alienta sobre este mandato legal, que así pierde una oportunidad fundamental para paralizar la acción municipal.

- La Sentencia del Tribunal Superior de Justicia de Andalucía de 27 de abril de 1999, pendiente de casación, al tratar una impugnación de la misma naturaleza, entiende que la infracción jurídica se produce ya con la aprobación del Presupuesto del Ayuntamiento en donde no se respeta la afectación legal de recursos del PMS, resolución que estimamos mucho más correcta y que quizá podría reorientar la posición inicial del Tribunal Supremo anteriormente aludida.

- La no aplicación del mandato legal de afectación de recursos del $P M S$ se ha relacionado con las diversas dificultades u obstáculos que se han venido presentando, la deficiente regulación de los mismos, la complejidad y coste de la gestión municipal necesaria al respecto, la insuficiencia de medios financieros en manos de los Ayuntamientos, así como la necesidad de insertar las programaciones municipales de suelo dentro de políticas a largo plazo, reñidas con el intento de los logros de tipo inmediato, únicos que ofrece la realidad municipal.

- La obligación legal de afectación de recursos del PMS, impuesta a los Ayuntamientos, deriva de una norma de acción que tan sólo contempla «intereses legítimos», y no configura derechos subjetivos («intereses directos») a favor de los administrados, circunstancia que, como todas las obligaciones impuestas a las Administraciones públicas bajo este tipo de normas: 
- Exigen el establecimiento de sistemas o procedimientos de control, presupuestarios o contables, que aseguren, con un mínimo realismo, su cumplimiento.

- Explican, al menos en buena parte, la escasa, por no decir prácticamente nula, conflictividad jurisdiccional sobre sus numerosos y repetidos incumplimientos.

- La supresión de la tutela financiera de tipo administrativo sobre la Administración local y la de sus Presupuestos especiales de Urbanismo privó de dos elementos que deberían haber garantizado, entre otros, y referidos a los PMS, el cumplimiento de la afectación legal de sus recursos, y que tampoco lo hicieron en tales períodos de tiempo, ya que las autoridades centrales, en el orden administrativo (Ministerio de la Vivienda, posteriormente Ministerio de Obras Públicas y Urbanismo) y en el ámbito financiero (Ministerio de Hacienda) no se preocuparon específica y puntualmente de dichas obligaciones, ni establecieron tampoco estructuras presupuestarias adecuadamente destinadas a la fácil comprobación del cumplimiento de tales mandatos.

- En la actualidad, la forma de entender, en la práctica, el contorno de la autonomía municipal, el régimen de presupuesto único, la existencia de una estructura presupuestaria inadecuada, la configuración - tan desdibujada e insuficiente- de las funciones de control interno y su desconexión con el ámbito del control externo completan un conjunto de circunstancias escasísimamente propicias para la hipotética supervisión de la obligación legal de nuestra referencia.

- En el ámbito presupuestario y contable, las deficiencias y omisiones que más saltan a la vista en la gestión económica de los PMS hacen referencia:

- A la aplicación del principio de presupuesto único, como fórmula general para programar y contabilizar la gestión económica anual, lo que en la práctica hace diluir la especificidad y singularidad de la "gestión urbanística» dentro de la gestión municipal general.

- A los Presupuestos de las Gerencias Municipales de Urbanismo, así como los de los Organismos autónomos y Sociedades mercantiles de dicha naturaleza, que no tienen regulación general, legal ni reglamentaria, que permita la singularización o desagregación de dichos aspectos de afectación en la gestión urbanistica, lo que dificulta a todos los efec- 
tos de cualquier tipo de control su debida separación del resto de operaciones.

- A las omisiones normativas presupuestarias y contables evidenciadas en la LRHL, RP, OMEP1989 ${ }^{91}$ e ICAL ${ }^{92}$, donde no sólo se observa la falta de una adecuada regulación de las necesarias rúbricas presupuestarias sobre el PMS, sino y lo que es más importante — dada la aplicación del «presupuesto único»— de las determinaciones concretas para reflejar al fin de ejercicio, con ocasión de la Liquidación y de la Cuenta General, el movimiento total de recursos (derechos) y gastos (obligaciones), ingresos y pagos, relativos a la gestión de dichos patrimonios, y la diferenciación de los ajustes que por tal gestión deba hacerse en el Resultado Presupuestario y en el Remanente de Tesorería.

- A la ubicación presupuestaria de tres recursos, que teniendo por su naturaleza económica una calificación de ingresos de capital, a los efectos de la Contabilidad Nacional, han sido aplicados, con evidente error, por parte del Ministerio de Economía y Hacienda, entre los «ingresos corrientes» del estado de ingresos de los Presupuestos de las Entidades Locales, como son las contribuciones especiales, las compensaciones por gastos de urbanización (cuotas de urbanización) y los ingresos derivados de la sustitución del aprovechamiento urbanístico correspondiente a la administración por su equivalente metálico.

Las cuotas de urbanización también constituyen un «ingreso de capital» por corresponderse, de una sola vez, con los gastos de primer establecimiento que supone la actividad urbanística, de ahí que el pretendido carácter de «contraprestación» que ha querido verse en su trasfondo no pueda, en modo alguno, por su inconsistencia, avalar su indebida ubicación entre los ingresos corrientes (Capítulo 3, «Tasas y otros ingresos», conceptos 370/396/399) ${ }^{93}$.

\footnotetext{
91 Orden del Ministerio de Economía y Hacienda de 20 de septiembre de 1989, por la que se establece la estructura de los Presupuestos de las Entidades Locales (BOE n. ${ }^{\circ} 252$, de 20 de octubre; corrección de errores $B O E$ n. ${ }^{\circ} 290$, de 4 de diciembre), modificada parcialmente por la Orden del Ministerio de Economía y Hacienda de 8 de septiembre de 1999 (BOE n. ${ }^{\circ} 228$, de 23 de septiembre).

92 Instrucción de Contabilidad para la Administración Local, aprobada por Orden del Ministerio de Economía y Hacienda de 17 de julio de 1990 (suplemento al BOE n. ${ }^{\circ} 175$, de 23 de julio), con modificaciones parciales por OOMM de 17 de junio ( $B O E$ n. ${ }^{\circ} 163$, de 9 de julio) y 18 de noviembre de 1999 (BOE n. ${ }^{\circ} 289$, de 3 de diciembre).

93 Éste es el criterio de la consulta 1/1993, evacuada por la IGAE (Boletín Informativo, n. ${ }^{\circ}$ 7, enero-febrero 1993, pp. 291-301).
} 
Los ingresos sustitutivos del aprovechamiento urbanistico constituyen también otros «ingresos de capital», por tener la misma naturaleza económica que los otros dos acabados de citar y, por tanto, no podemos coincidir con su conceptuación como operaciones corrientes puestas de manifiesto «como consecuencia de una actividad típica y normal de los Entes públicos, cual es la urbanística», ya que dicha tipicidad y normalidad no están reñidas con la verdadera calificación económica de tales recursos como opuestos a los corrientes, ya que se derivan, se originan y se orientan o aplican a gastos de primer establecimiento en el orden urbanístico ${ }^{94}$.

- El informe sobre el Presupuesto General de las Entidades Locales, atribuido a la Intervención, de forma desdibujada e imperfecta, no cuenta con recursos complementarios para promover un hipotético recurso contra las infracciones legales de dicho documento, que tampoco se puede obtener por la vía indirecta de dar conocimiento al Tribunal de Cuentas, quedando todo en una eventual «acción popular»; la posible impugnación (norma «de acción»), de lo que comporta — en nuestro caso - una desnivelación presupuestaria.

- El seguimiento de las incidencias que tal gestión urbanística haya dejado trazo en la contabilidad, o debiera haberlo dejado, no queda sino reconducido a la técnica de gastos con financiación afectada que, de no haber sido debidamente completada por el órgano de control interno en ejercicio de sus tareas contables, y que, además, deberían pasar el tamiz de los acuerdos municipales de la Liquidación y Cuenta General, donde habrían de calcularse y especificarse las desviaciones de financiación en que se hubiera incurrido, provocando los necesarios ajustes en el documento de Remanente de Tesorería, tendrían una gran dificultad para ser reconstruidos - siempre con una labor singularizada y lenta — por los órganos de control externo.

En el mejor de los casos, es decir, en aquéllos en que el órgano de gestión contable (Intervención de la Entidad Local) hubiera podido calcular exactamente las aludidas «desviaciones de financiación» por desajuste entre la dinámica de recursos (derechos) y gastos (obligaciones) respecto de la gestión del PMS, y que éstas, reflejadas como ajustes, aparecieran en el Remanente de Tesorería, recibieran la aprobación de la Presidencia (Liquidación) y del Pleno (Cuenta General), queda latente el problema de fondo, reflejado por la doctrina más sensible a los aspectos económicos de la gestión urbanística, en supuestos de muy significativas «desviaciones», de las

94 Su consideración como operaciones corrientes se explicita en la consulta 9/1993, evacuada por la IGAE (Boletín Informativo, n. ${ }^{\circ} 11$, septiembre-octubre 1993, pp. 155-161). 
dificultades prácticas de salir al paso de ellas — como cuestiones de tesorería-, por tenerse que balancear o financiar en definitiva por los restantes recursos ordinarios o corrientes municipales, verdadero y casi único punto de referencia de la solvencia financiera de la Corporación.

Esta «técnica» de los ajustes por desviaciones de financiación en la gestión de los PMS, en el documento de Remanente de Tesorería, sólo constituye en definitiva - y en el mejor de los casos-, que ya es ser optimista, una mera constatación de los desajustes o irregularidades gestoras, por lo que nada o muy poco colaboran para evitar o enmendar la gestión incorrecta, cuando no abiertamente ilegal, que precisan de otros mandatos en la vertiente presupuestaria y contable, con el debido reflejo, con visos de eficacia, en las funciones de control y su conexión (interno y externo).

\section{ADDENDA}

Una vez concluido el presente trabajo, hemos tenido noticia de una decisiva Sentencia del Tribunal Supremo sobre el tema de la afectación de recursos del Patrimonio Municipal del Suelo objeto de nuestra atención y estudio.

Se trata de la STS (Sala Quinta) de 2 de noviembre de 2001 (Recurso de Casación número 4.735/96), en cuyo Fallo se anula el Acuerdo del Ayuntamiento de Oviedo aprobando su Presupuesto General Municipal para 1994, «que declaramos disconforme a Derecho únicamente en cuanto en dicho Presupuesto no se reinvierte en conservación y ampliación del Patrimonio Municipal del Suelo el importe de las enajenaciones que en él se prevén de terrenos de dicho Patrimonio», por lo que «anulamos el Acto recurrido en ese extremo».

La referida STS de 2 de noviembre de 2001 incorpora en su Fundamento Jurídico Sexto una parte importante de la STS de 2 de noviembre de 1995.

\section{ABREVIATURAS UTILIZADAS}

GMUM

ICAL
Gerencia Municipal de Urbanismo de Madrid.

Instrucción de Contabilidad para la Administración Local, aprobada por Orden del Ministerio de Economía y Hacienda de 17 de julio de 1990. 
IGAE

LAM

LBRL

LJ

LRHL

LRL 1950

LRL 1955

LRU 1990

LS 1956

LS 1975

OMEP 1989

PMS

RAM

RB 1955

RHAL

RP

STC

STS
Intervención General de la Administración del Estado.

Ley 121/1963, de 2 de diciembre, sobre el Área Metropolitana de Madrid.

Ley 7/1985, de 2 de abril, Reguladora de las Bases del Régimen Local.

Ley 29/1998, de 13 de julio, Reguladora de la Jurisdicción Contencioso-Administrativa.

Ley 39/1988, de 28 de diciembre, Reguladora de las Haciendas Locales.

Ley de Régimen Local, Texto articulado aprobado por Decreto de 16 de diciembre de 1950.

Ley de Régimen Local, Texto articulado y refundido, aprobado por Decreto de 24 de junio de 1955.

Ley 8/1990, de 25 de julio, de Reforma del Régimen Urbanístico y Valoraciones del Suelo.

Ley de Régimen del Suelo y Ordenación Urbana de 12 de mayo de 1956.

Ley 19/1975, de 2 de mayo, de Reforma de la Ley sobre Régimen del Suelo y Ordenación Urbana.

Orden del Ministerio de Economía y Hacienda de 20 de septiembre de 1989 por la que se establece la estructura de los Presupuestos de las Entidades Locales.

Patrimonio Municipal del Suelo.

Reglamento del Área Metropolitana de Madrid, aprobado por Decreto 3088/1964, de 28 de septiembre.

Reglamento de Bienes de las Entidades Locales, aprobado por Decreto de 27 de mayo de 1955.

Revista de Hacienda Autonómica y Local.

Reglamento Presupuestario, aprobado por Real Decreto $500 / 1990$, de 20 de abril.

Sentencia del Tribunal Constitucional.

Sentencia del Tribunal Supremo. 
TRfdo.LS 1976 Texto Refundido de la Ley 19/1975, de 2 de mayo, sobre Régimen del Suelo y Ordenación Urbana, aprobado por Decreto 1346/1976, de 9 de abril.

TRfdo.LS 1992 Texto Refundido de la Ley sobre Régimen del Suelo y Ordenación Urbana, aprobado por Real Decreto Legislativo $1 / 1992$, de 26 de junio.

\section{BIBLIOGRAFÍA}

AguinAGA MARTíNEZ, Miguel: «Fiscalización en materia de urbanismo» en la obra colectiva El control interno en las Corporaciones Locales (abril-mayo 1997), Colegio Oficial de Secretarios, Interventores y Tesoreros de Administración Local de Castellón, Servicio de Publicaciones de la Diputación de Castellón, Castellón de la Plana, 1997.

Alarcón García, Gloria: El Presupuesto general de los municipios, Editorial Tecnos, S. A., Madrid, 1996.

AMORÓs RICA, Narciso (Director) y otros: Comentarios a las Leyes Tributarias y Financieras (Tomo XLI, Vol. 1. ${ }^{\circ}$, Ley General Presupuestaria. Artículos 1 a 74), 2. a edición, Editorial Colex, Madrid, 1987.

ARNAU BERNIA, Vicente J.:

— «Anotaciones sobre los principios de unidad y nivelación en los Presupuestos de las Entidades Locales"), RHAL, vol. XVIII, n. ${ }^{\circ}$ 53, mayo-agosto 1988, Ed. de Derecho Reunidas. Ed. de Derecho Financiero, Madrid, 1988.

— «El régimen presupuestario local vigente: el presupuesto "único"», PALAU 14. Revista Valenciana de Hacienda Pública, enero-abril 1989.

— «El régimen presupuestario de las Entidades Locales», RHAL, vol. XX, n. ${ }^{\circ} 58$, enero-abril 1990.

- Manual de Presupuestos de las Entidades Locales, Monografías Jurídicas, Marcial Pons, Ediciones Jurídicas, S. A., Madrid, 1991.

- «La gestión presupuestaria de las Entidades Locales». Presupuesto y Gasto Público, n. ${ }^{\circ}$ 8/1992, Ministerio de Hacienda, Madrid, 1992. 
- «Acotaciones a la reforma presupuestaria y contable de las Entidades Locales», El Consultor de los Ayuntamientos, n. ${ }^{\circ} 23$ extra, Madrid, 1992.

- El saneamiento de las Haciendas Locales, Federación de Municipios de la Región de Murcia, Murcia, 1999.

BASSOLS COMA, Martín: Génesis y evolución del Derecho urbanistico español, 1812-1956, Editorial Montecorvo, Madrid, 1973.

BoQuera OlIVER, José M. a.: «El Patrimonio municipal del suelo», en el volumen Problemas del Urbanismo Moderno (Conferencias del Curso 1965-66), Instituto de Estudios de Administración Local, Madrid, 1967.

CARRETERo PÉREZ, Adolfo: «Las Haciendas locales y la gestión económica del urbanismo», Revista de Economía y Hacienda Local, vol. IV, n. ${ }^{\circ}$ 12, septiembre-diciembre 1974, Editorial de Derecho Financiero, Madrid, 1974.

CASTILlo Gómez, Fátima: «Los Patrimonios Municipales del Suelo: destino y finalidad», Revista El Consultor, n. ${ }^{\circ}$ 21, Madrid, 15-noviembre-2000.

CORRAL GARCÍA, Esteban: «El Patrimonio Municipal del Suelo», Revista El Consultor de los Ayuntamientos, n. ${ }^{\circ}$ 9, Madrid, 15 de mayo de 1994.

DíAZ LeMA, José Manuel: «El Patrimonio Municipal del Suelo en el Texto Refundido de 1992», en el Curso sobre el Texto Refundido de la Ley del Suelo de 26 de junio de 1992, Gerencia Municipal de Urbanismo. Ayuntamiento de Madrid, 1993. También en Revista de Derecho Urbanístico, n. ${ }^{\circ}$ 136, Editorial Montecorvo, Madrid, 1994.

ESTÉVEZ GOYTRE, Ricardo: Manual de Derecho Urbanístico. Tras la Ley 6/1998, de 13 de abril, sobre Régimen del Suelo y Valoraciones. Doctrina, Legislación y Jurisprudencia, 2. ${ }^{a}$ Edición, Editorial Comares, S. L., Granada, 2000.

EzQuiaga Domínguez, Ignacio; EzQuiaga Domínguez, José M.a: «Urbanismo y Haciendas Locales», Análisis Local, n. ${ }^{\circ} 12$, mayo-junio, 1997, Madrid. 
FERNÁNDEZ RoDRÍGUEZ, Tomás-Ramón: Manual de Derecho Urbanístico, Publicaciones Abella, Madrid, 1980.

- Manual de Derecho Urbanístico, 13. a edición, Publicaciones Abella, Madrid 1998.

- Manual de Derecho Urbanístico, 14. . edición, Publicaciones Abella, Madrid, 1999.

- Manual de Derecho Urbanístico, 15. a edición, Publicaciones Abella, Madrid, 2000.

Ferrán SAlvador, Federico A.: Contabilidad Municipal. Establecimiento Litográfico de José Martínez, Barcelona, 1900.

FONSECA FERRANDIS, Fernando E.: El régimen jurídico de los patrimonios municipales del suelo, Universidad Carlos III de Madrid-Boletín Oficial del Estado, Madrid, 1995.

FonSECA FERRANDIS, Fernando E.: «Intervención Pública en el Mercado del Suelo», en la obra colectiva Derecho Urbanístico de la Comunidad de Madrid (PAREJO Alfonso, Luciano: Director), Instituto Pascual Madoz del Territorio, Urbanismo y Medio Ambiente, Universidad Carlos III de Madrid y Marcial Pons, Ediciones Jurídicas y Sociales, Madrid-Barcelona, 1998.

GARCÍA DE ENTERRÍA, Eduardo; PAREJO ALFONSO, Luciano: Lecciones de Derecho Urbanistico, Editorial Civitas, S. A., Madrid, 1981.

GARCÍA DE ENTERRÍA, Eduardo; FERnÁNDEZ RodRÍGUEZ, Tomás-Ramón: Curso de Derecho Administrativo, 6. ${ }^{a}$ edición, Editorial Civitas, S. A., Madrid, 1999.

GARCÍA FLÓREZ, Fernando: «Nuevas perspectivas del Patrimonio Municipal del Suelo: Régimen Jurídico aplicable. Su instrumentalidad técnica», Revista El Consultor, n. ${ }^{\circ}$ 22, Madrid, 30 de noviembre de 1995.

GARRIDO FALla, Fernando: Tratado de Derecho Administrativo, 12. edición, Ed. Tecnos, S. A., Madrid, 1994.

GONZÁLEZ-BERENGUER URRUTIA, José Luis: La financiación del Urbanismo y el precio de los terrenos, Colección Autonómica y Local, Editorial Montecorvo, S. A., Madrid, 1997. 
GONZÁLEZ GARCÍA, Julio V.: «La intervención pública en el mercado del suelo en la legislación urbanística de la Comunidad de Madrid», en la obra colectiva El Derecho Urbanistico en la Comunidad de Madrid (dirigida por Miguel SÁNCHEZ MORÓN), Editorial Lex-Nova, Valladolid, 1999.

GONZÁlez PÉREZ, Jesús: Comentarios a la Ley del Suelo, 4. ${ }^{a}$ edición, Editorial Civitas, S. A., Madrid, 1981.

- Comentarios a la Ley del Suelo (Texto Refundido de 1992), 6. ${ }^{\mathrm{a}}$ edición, Editorial Civitas, S. A., Madrid, 1993.

LAMPREAVE, José L.: «La financiación del urbanismo (un acercamiento a su fundamentación doctrinal y a la evaluación de sus resultados en España)», Hacienda Pública Española, n. ${ }^{\circ}$ 22, Instituto de Estudios Fiscales, Madrid, 1973.

LÓPEZ-JURADO ESCRIBANO, Francisco de Borja: Los patrimonios municipales del suelo. Sus caracteres y operatividad, CEMCI, Granada 1992.

Lliset Borrell, Francisco; LÓPEZ Pellicer, José A. y ROMERo HernÁNDEZ, Federico: Ley del Suelo. Comentarios al Texto Refundido de 1992, Publicaciones Abella, Madrid, 1993.

MARTÍN HERNÁNDEZ, Paulino: «El destino de los bienes integrados en el patrimonio municipal del suelo», Análisis Local, n. ${ }^{\circ} 6$ (mayo-junio 1996), Edit. Consultores de las Administraciones Públicas, Madrid, 1996.

MARTín VALDIVIA, Salvador M.': Urbanismo y especulación. Los Patrimonios Públicos del Suelo, Editorial Montecorvo, Madrid, 1998.

MARTÍNEZ GARcíA, José Ignacio: Aspectos Económicos y Tributarios del Urbanismo, Editorial Bayer Hermanos, S. A., Barcelona, 2001.

MartíneZ Lago, Miguel Ángel: Manual de Derecho Presupuestario, Editorial Colex, Madrid, 1992.

MENÉNDEZ REXACH, Ángel: «Reflexiones sobre el significado actual de los patrimonios públicos», en Ciudad y Territorio, n. ${ }^{\text {os }}$ 95-96, pp. 209-221. Editada por el Centro de Publicaciones de la Secretaría General Técnica del Ministerio de Fomento, Madrid, 1993. 
MuRILlO CERRATO, Agustín: «Régimen económico, financiero y presupuestario de las Gerencias de Urbanismo», en la publicación Encuentro de Gerencias Municipales de Urbanismo, Gerencia Municipal de Urbanismo, Ayuntamiento de Madrid, 1994.

NIETO, Alejandro: La «nueva» organización del desgobierno, 1. ${ }^{\mathrm{a}}$ edición, 1. reimpresión, Editorial Ariel, S. A. Barcelona, 1997.

Palao Taboada, Carlos: Derecho Financiero y Tributario, vol. I (Introducción. Derecho Presupuestario. Ingresos públicos no tributarios), 2. ${ }^{a}$ edición, Editorial Colex, Madrid, 1987.

Parejo Alfonso, Luciano (dir.).: Derecho Urbanístico de la Comunidad de Madrid, Instituto Pascual Madoz del Territorio, Urbanismo y Medio Ambiente, Universidad Carlos III de Madrid y Marcial Pons, Ediciones Jurídicas y Sociales, Madrid-Barcelona, 1998.

PÉREZ BOTIJA, E.: «Introducción al Derecho Urbanístico Español», primera parte del Derecho Urbanístico Español (Conceptos y Legislación), Instituto de Estudios de Administración Local, Madrid, 1950.

PÉREZ Moreno, Alfonso: «Aspectos jurídicos del Patrimonio Municipal del Suelo», Revista de Derecho Urbanístico, n. ${ }^{\circ}$ 10, Editorial Montecorvo, Madrid, 1968.

QuintanA LóPEZ, Tomás y LoBATO GóMEZ, J. Miguel: La constitución y gestión de los Patrimonios Municipales del Suelo, Marcial Pons. Ediciones Jurídicas y Sociales, S. A., Madrid, 1996.

RoDríguez BEREIJO, Álvaro: Introducción al estudio del Derecho Financiero. Un ensayo sobre los fundamentos teóricos del Derecho Financiero, Colección: Estudios de Hacienda Pública, Instituto de Estudios Fiscales, Ministerio de Hacienda. Madrid, 1976.

RODRIGO MORENO, Fernando: «Tres problemas urbanísticos: integración de los edificios en el Patrimonio Municipal del Suelo, destino de los bienes integrantes de este patrimonio y extensión subjetiva de la carga real en el sistema de compensación», Revista El Consultor, n. ${ }^{\circ}$ 6, Madrid, 30 marzo 2000.

SANTOS DieZ, Ricardo, CASTElaO RodRíGUEZ, Julio: Derecho Urbanístico, 4. ${ }^{a}$ edición, El Consultor, Madrid, 2001. 
SAURA PACHECO, Antonio: Nuevo sistema de contabilidad municipal, Colegio Nacional de Secretarios, Interventores y Depositarios de Administración Local, Madrid, 1947.

SAURA PACHECO, Antonio: Teoría y práctica de los Presupuestos municipales, Ediciones Municipalía, Madrid, 1958.

SERRANO GUIRADO, Enrique: «Planificación territorial, Política del suelo y Administración local», en Problemas Políticos de la Vida Local, tomo III, Madrid, 1963. 